HERANCA DA RESISTÊNCIA A MURCHA DE Phytophthora EM PIMENTAO NA FASE JUVENIL.

\author{
CLÁUD I A S ILVA \\ Engenheira Agrônoma
}

Orientador: Dr. Itamar Soares de Melo

Dissertação apresentada à Escola Superior de Agricultura "Luiz de Queiroz", da Universidade de São Paulo, para obtenção do título de Mestre en Agronomia, Área de Concentração: Genética e Melhoramento de Plantas.

PIRACICABA

Estado de São Paulo - Brasil

Dezembro - 1992 
Ficha catalografica preparada pela Seça de Livros da Divisão de Biblioteca e Documentaçăo - FCLQ/USP

\section{Silva, Cláudia}

S586h Herança da resistência à murcha de Phytophthora em pimentão na fase juvenil. Piracicaba, 1992.

p.

Diss. (Mestre) - ESALQ

Bibliografia.

1. Fungo fitopatogênico 2. Murcha do pimentão 3. Pimentão Doença - Resistência 4. Pimentão - Melhoramento I. Escola Supe rior de Agricultura Luiz de Queiroz, Piracicaba 
heranca da RESTSTÊNCIA A MURCHA dE PHytophthora FiM PIMENTÃO NA JUVENIL

CLÁUDIA SILVA

Aprovada em: 12.02.1993

Comissão julgadora:

Dr. Itamar Soares de Melo CNPDA/EMBRAPA prof. Dr. Isaias Olivio Geraldi ESALQ/USP Prof. Dr. Hiroshi Kimati ESALQ/USP

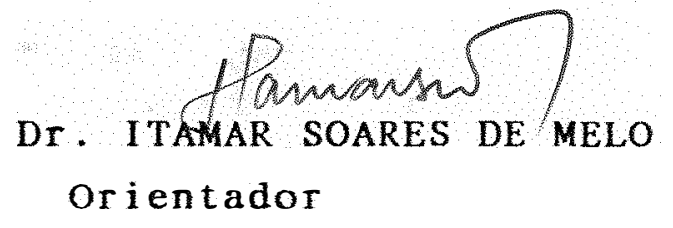




\section{AGRADECI MENTOS}

Meus sinceros agradecimentos a:

Alvacir Alberto Fedalto

Antônio Olfmpio dos Santos

Carlos Alberto Lopes

Francisco Terasaua JT.

Gilmar Jaulo Henz

Joào Soares Filho

Jorge Roland $M$. dos Santos

José Branco de Miranda Filho

leonardo de Brito Giordano

Maria Fal ima B. F. Lima

Ossami Furumoto

Paulo Eduardo de Melo

Pedro Pereira da Silua

e ainda a :

ESALQ/USP

Departamento de Genética

CNPq

CNP Hortaliças/ EMBRAPA

e especialmente a:

Itamar Soares de Melo

Francisco J. B. Reifschneider 


\section{SUMARIO}

Página

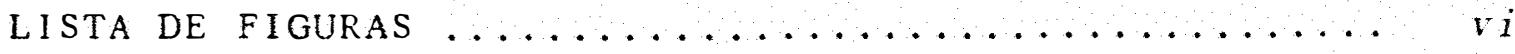

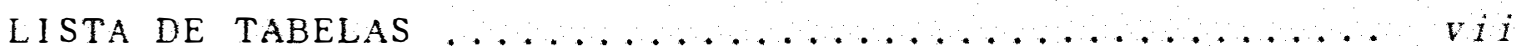

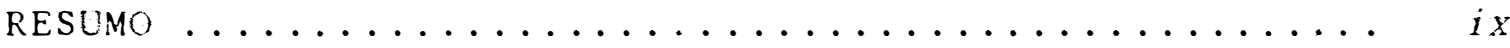

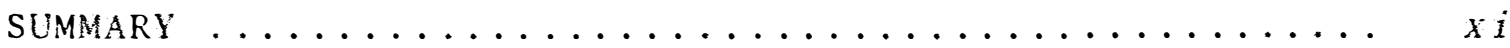

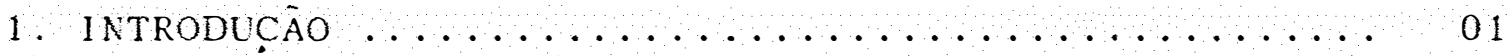

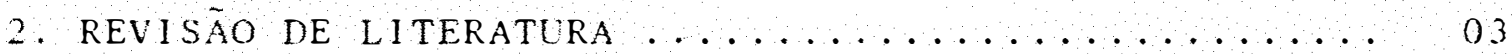

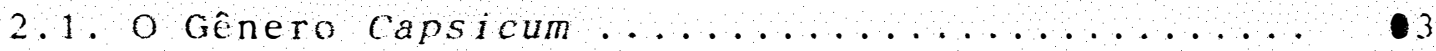

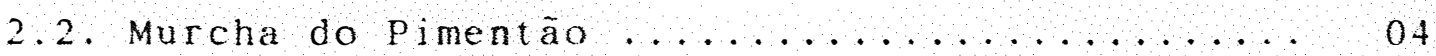

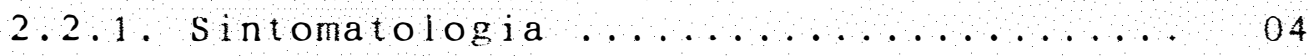

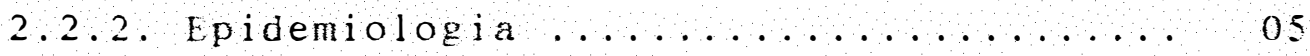

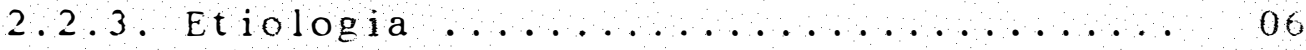

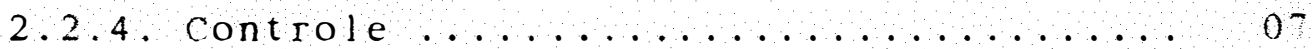

2.3. Resistência ...................... 8

2.3 .1 . Fontes de Resistência ............ 08

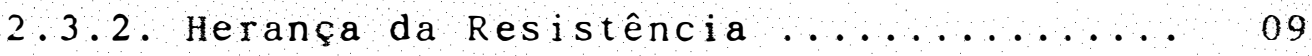

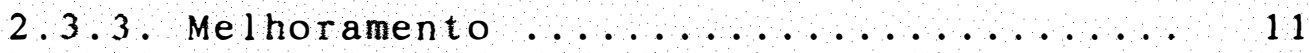

2.3.4. Influência de Fatores Ambientais ....... 12

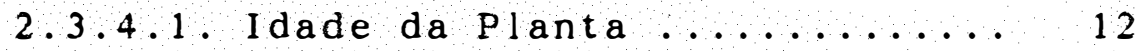

2.3.4.2. Métodos de Inoculação........ 13

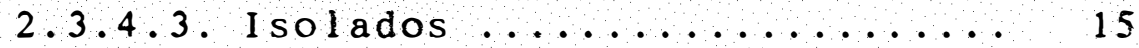

2.3.4.4. Concentração de Inoculo ...... 16

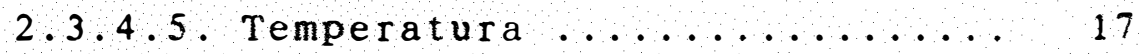

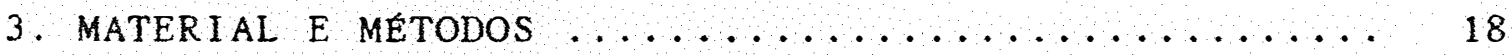

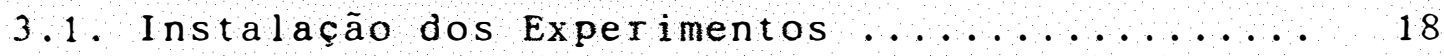

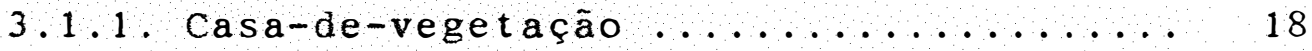

3.1 .2 . Produção de Inoculo ............... 19

3.1.3. Método de Inoculação e Aval i ação ........2 20

3.2. Padronização do Método de Aval iação da Res is -

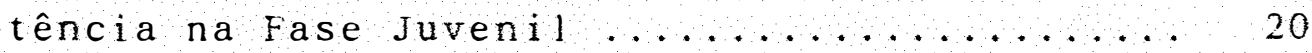

3.2.1. Efeito da Data de Avaliação apos a Ino-

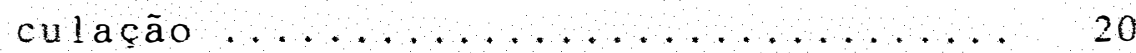


Página

3.2.2. Efeito da Concentração de Inoculo .... 21

3.2.3. Efeito da Idade da planta .......... 22

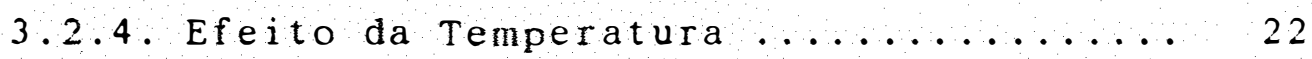

3.3. Avaliação da Resistência de Genótipos do BAG de Capsicum à phytophthora .............. 23

3.4. Estudo de Herança da Resistência na Fase Ju-

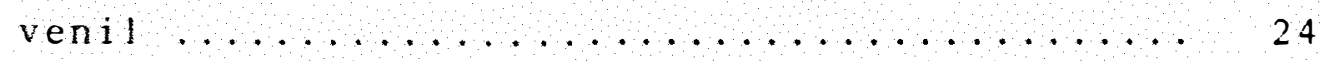

3.4 .1 . Genot ipos Ut i lizados _............24 24

3.4 .2 Cruzamentos $\ldots \ldots \ldots \ldots \ldots \ldots \ldots \ldots \ldots$

3.4 .3$. Ava 1 i ação ........................ 27

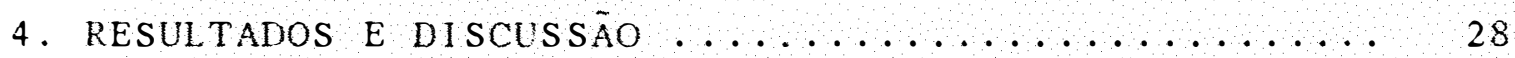

4.1. Padronização do Método de Aval iação da Resis -

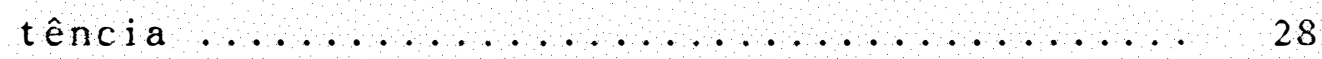

4.1.1. Efeito da Data de Aval iação......... 28

4.1.2. Efeito da Concentração de 1 noculo ..... 33

4.1.3. Efeito da Temperatura .................. 36

4.1.4. Efeito da ldade da Planta _.............. 38

4.2. Avaliação da Res istência na Fase Juvenil de Genotipos de Capsicum _................. 43

4.3. Estudo de Herança da Resistência .......... 51

4.4. Consideraçōes finais ................... 59

5. CONCLUSÖES $\ldots \ldots \ldots \ldots \ldots \ldots \ldots \ldots \ldots \ldots \ldots \ldots \ldots \ldots \ldots \ldots \ldots \ldots \ldots 60$

6. REFERÊNCIA BIBLIOGRÁFICAS $\ldots \ldots \ldots \ldots \ldots \ldots \ldots$ 


\section{LISTA DE FIGURAS}

Figura

Pagina

01.Numero médio de plantas tombadas dos genotipos CNPH 148,173 e 192 , do 32 ao 82 dias apos a inoculação (d.a.i.) com Phytophthora capsici

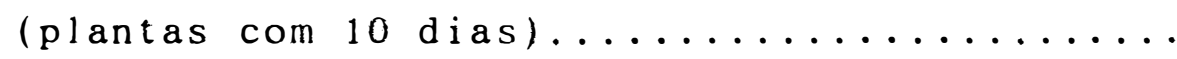

02. Numero médio de plantas tombadas dos genotipos CNPH 148,173 e 192 , do 32 ao 82 d.a.i. com Phytophthora capsici (plantas com 15 dias)...

03. Numero médio de plantas tombadas dos genotipos CNPH 148,173 e 192 , do 32 ao 82 d.a.i. com Phytophthora capsici (plantas com 20 dias)...

04. Efeito de seis concentrações de inbculo (zoosp $/ \mathrm{ml})$ de Phytophthora capsici sobre o numero de plantas tombadas dos genotipos CNPH 148,173

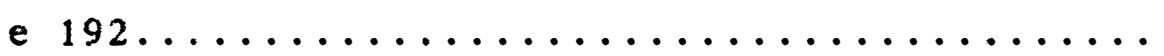

05. Numero médio de plantas tombadas de três genotipos de Capsicum annuum, inoculados com Phytophthora capsici em quatro idades dife-

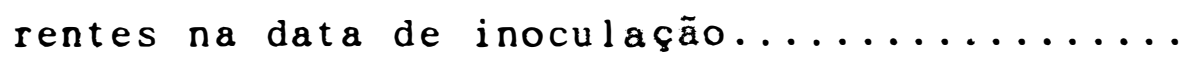

06. Efeito da idade da planta (dias apos a emergência) na data de inoculação com Phytophthora capsici sobre o numero de plantas tombadas de

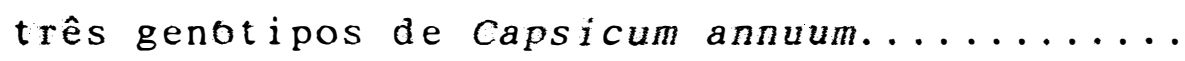

07. Esquema de destribuição de genotipos e fenotipos obtidos nas gerações $F_{1}, R C_{1}, R C_{2}$ e $F_{2}$ do cruzamento entre CNPH 148 e CNPH $192 \ldots \ldots . . .$. 
vi i

LISTA DE TABELAS

Tabela

Página

01. Genotipos de Capsicum sp. para resistência a

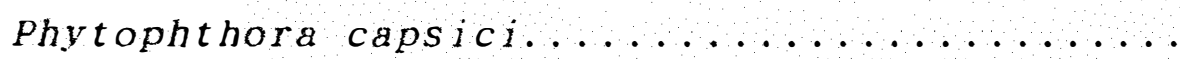

02. Numero médio de plantas tombadas de três genttipos de Capsicum annuum inoculados com três concentrações de inoculo de Phytophthora cap-

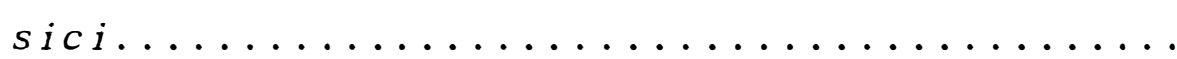

03. Efeito da temperatura no numero médio de plantas tombadas de três genotipos de Capsicum annuum, inoculados com Phytophthora capsici $\left(5 \times 10^{4}\right.$ zoosp./m 1$) \ldots \ldots \ldots \ldots \ldots \ldots \ldots \ldots \ldots \ldots \ldots \ldots \ldots \ldots \ldots \ldots$

04. Efeito da temperatura no numero médio de plantas tombadas de três genotilpos de Capsicum annuum inoculados com phytophthora capsici

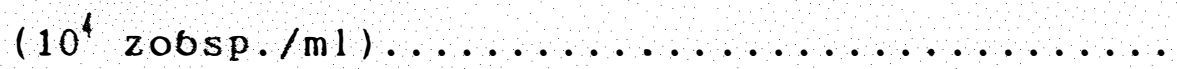

05. Numero médio de plantas tombadas de três genotipos de Capsicum annuum inoculados aos 7 e 14 dias apos a emergência (d.a.e.) com Phyto-

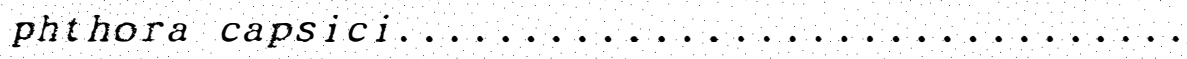

06. Reação de populações de Capsicum spp. a Phyto-

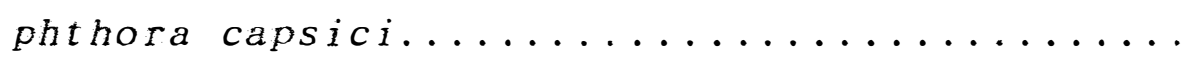

07. Reação de populações de Capsicum spp. a Phyto-

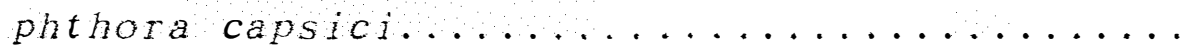


08. Reação de populações de Capsicum spp. a Phyto-

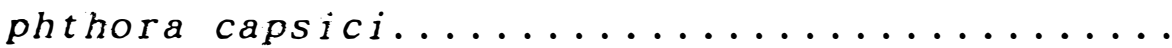

09. Reação de populações de Capsicum spp. a Phyto-

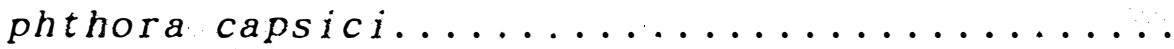

10. Reação de populações de Capsicum spp. a Phyto-

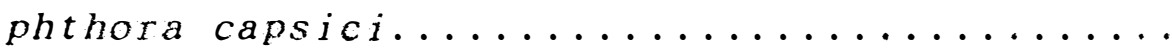

11. Comparaça entre cruzamentos reciprocos para resistência em capsicum annuum a Phytophthora

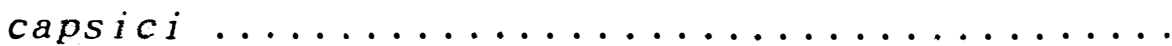

12. Dados de segregação para resistência em Capsicum annuum a Phytophthora capsici nas gerações parentais, Fl, retrocruzamentos e $F_{2}$ obtidos do cruzamento entre CNPH 148 e CNPH $192 \ldots . .$.

13.Dados de segregação para resistência em $C$. annuum a $P$. capsici as gerações parentais, $F_{\mathbb{l}}$, retrocruzamentos e $F_{2}$ obtidos do cruzamento entre $\mathrm{CNPH} 173$ e $\mathrm{CNPH} 192 \ldots \ldots \ldots \ldots$ 


\title{
HERANÇA DA RESISTÊNCIA À MURCHA DE Phytophthora EM PIMENTÃO NA FASE JUVENIL
}

\author{
Autora: CLÁUDIA SILVA \\ Orientador: DR. ITAMAR SOARES DE MELO
}

RESUMO

Determinou-se uma metodologia para avaliação da resistência de Capsicum na fase juvenil a Phytophthora capsici. Foram estudados os efeitos de idade de planta, concentração de zoosporos e temperatura sobre a expressão da resistência.

Os gentipos CNPH 148, CNPH 173 e CNPH 192 foram identificados como resistente, parcialmente resistente e suscetfvel, respectivamente, e foram usados nos cruzamentos para determinar o modo de herança na fase juvenil.

Uma concentração de $5 \times 10^{4}$ zoosporos/ml foi suficiente para causar tombamento em $100 \%$ das plantas do genotipo suscetílel sem, contudo, afetar a resposta do material resistente. Em relacão a temperatura, uma variação entre maxima de $26^{\circ} \mathrm{C}$ e minima de $16^{\circ} \mathrm{C}$ foram ideais para distinguir o genotipo resistente do suscetílel. A inoculação de plantas em diferentes idades mostrou que CNPH 148 foi resistente quando inoculado aos 7 e 14 dias apos a emergência (d.a.e.). O genotipo CNPH 173 mostrou alta instabilidade. variando de resistente a parcialmente resistente.

A avaliação de 80 introduções do Banco de Germoplasma do CNPH/EMBRAPA permitiu a identificação de 12 fontes de resistência na fase juvenil a P. capsici: CNPH 134, 
$989,287,1398,2171,2172,2174,1397,2176,1386,2175 \mathrm{e}$ 2661 .

A base genética da resistência.na fase juvenil foi estudada inoculando-se plântulas com 15 d.a.e.. Os progenitores e as geraçōes $F_{1}$, retrocruzamentos e $F_{q}$ de dois materiais resistentes e um suscetivel foram avaliados em casa-de-vegetação. A segregação nas gerações $F_{\hat{\imath}}$ obtidas dos cruzamentos entre CNPH 148 X CNPH 192 e CNPH 173 X CNPH 192 foi de 13R: 35 , indicando que a resistência é conferida por dois genes com epistasia dominante e recessiva. As flutuaçós observadas dentro das classes fenotfpicas podem ser explicado por uma penetrância incompleta dos genes devido a presença de genes menores modificadores. 
INHERITANCE OF RES ISTANCE TO Phytophthora BLIGHT

IN SWEET PEPPER AT THE JUVENILE AGE

Author: CLAUDIA SILVA

Adviser: DR. ITAMAR SOARES DE MELO

\section{SUMMARY}

A standard method for evaluation of resistance of Capsicum in the juvenile age to phytophthora capsici was determined. The effects of plant age, zoospore concentration and temperature on the resistance expression were studied.

The genotypes CNPH 148, CNPH 173 and CNPH 192 were identified as resistant, partly resistant and susceptible, respectively, and were used in crosses to determine the mode of inheritance in the juvenile age.

An inoculum concentration of $5 \times 10^{4}$ zoospores $/ \mathrm{ml}$ was sufficient to damp off all susceptible plants without affecting the reaction of the resistant genotypes. Regarding to the temperature, 16 to $26^{\circ} \mathrm{C}$ was tehe range ideal to destinguish resistant from susceptible genotypes. The inoculation of plants at different ages showed that CNPH 148 was resistant when inoculated either at 7 and 14 days after the emergence. CNPH 173 showed high instability, varying from resistant to partly resistant.

The evaluation of 80 introductions of the CNPH/EMBRAPA germoplasm bank allowed the identification of 12 sources resistance of at the juvenile age: CNPH 134, 989 , $287,1393,2171,2172,2174,1397,2176,1386,2175$ and 2661. 
The genetic basis of resistance at the juvenile age was studied by inoculating 15 day old seedlings. Progenitors, $F_{l}$, backcrosses and $F_{?}$ populations of the two resistant and one susceptible materials were tested in greenhouse. The $F_{2}$ generations $(148 \times 192$ and $173 \times 192)$ fitted a 13 resistant : 3 susceptible ratio, which indicates a inheritance governed by 2 genes for resistance with dominant and recessive epistasis. The fluctuations within the fenotypic classes may be explained by incomplete penetrance of the resistant genes due to the presence of minor modifying genes. 
1. INTRODUCCÃO

A murcha-de-fitoftora, cujo agente etiologico é o fungo phytophthora capsici Leonian, é uma das doenças mais importantes da cultura do pimentão (Capsicum annuum L.). limitando sua produção em muitas areas do mundo e também do Brasil, nos estados de Minas Gerais, São Paulo, Distrito Federal, Goias e Rio de Janeiro. Foi identificada pela primeira vez no Brasil no estado de São Paulo, em 1951, causando sérios prejuizos a cultura do pimentão. Embora a doença seja favorecida por clima quente e chuvoso, quando ocorre com frequência a perda total dos plantios, o fungo tem causado sérios prejurzos em qualquer época do ano, em todos os locais onde se cultiva pimentão no Brasil.

o patogeno P.capsici ataca primeiramente o sistema radicular e o colo da planta, podendo também atacar a parte aérea. As plântulas sofrem murcha da parte aérea, em consequência da morte das rafzes e necrose do colo; em seguida ocorre o tombamento.

Por ser um fungo do solo, o controle qúf mico é diff́cil e economicamente inviável. O uso de cultivares resistentes é o método mais eficiente de controle.

Apesar de terem sido identificadas várias fontes de resistência e o modo de herança do caráter, não existe atualmente no mercado cultivares de pimentão resistentes a murcha-de-fitoftora. Isto pode ser explicado pelo uso de métodos de melhoramento inadequados e pelos critérios irregulares adotados durante o processo de seleção, 
como método de inoculação, idade da planta, concentração de inoculo, isolado do fungo e temperatura. Existem relatos de quebra de resistência em germoplasmas de pimenta e pimentão quando inoculados na fase juvenil.

Pesquisas considerave is têm sido feitas para identificar um tipo de resistência estavel e duravel a P.capsici, que se manifeste desde o estadio juvenil da planta. Além disso, a seleção de genotipos de Capsicum resistentes a $P$. capsici em plântulas permite ao melhorista a vantagem de trabalhar com uma população segregante grande, com economia de espaço e tempo.

Este trabalho teve como objetivo:

a) Padronizar metodologia de avaliação de resistência na fase juvenil em C.annuum a P.capsici;

b) Identificar novas fontes de resistência na fase juvenil de pimenta e pimentão a P.capsici;

c) Estudar a herança genética da resistência na fase juvenil de C.annuum a P.capsici. 
2. REVISÃO DE LI TERATURA

2.1. O Gênero Capsicum

Capsicum é um gênero da famr lia Solanaceae, que cobre muitas espécies importantes economicamente como batata (Solanum tuberosum L.), berinjela (S.melongena L.), tomate (Lycopersicum esculentum Mill.) e tabaco (Nicotiana tabacum L.) (GOVINDARAJAN, 1985).

Cerca de 20 a 30 espécies de Capsicum foram relatadas como tendo a sua origem no Novo Mundo. Linnaeus descreveu duas espécies, C.annuum e C.frutescens, em seu livro "Species plantarum" e adicionou duas outras anos mais tarde. Atualmente, cinco espécies são conhecidas como cultivadas: C.annuum, C.frutescens, C.chinense, C.baccatum e C.pubescens (HEISER \& SMITH, 1953). Todas as cinco possuem espécies selvagens afins, com as quais apresentam possibilidades de troca de genes (CASAL \& COUTO, 1984). Essas espécies selvagens não foram avaliadas cuidadosamente, mas aparentemente contêm fontes uteis de resistência a vírus, bactérias e doenças fungicas (IBPGR, 1983).

C.annuum é extensivamente cultivada, enquanto que na América Latina a forma cultivada é C.chinense e nos EUA, leste da Áfica e uma parte da India é C.frutescens. As outras duas espécies, C.baccatum e C.pubescens são cultivadas somente na América do Sul (GOVInDARAJAN, 1985).

Todas as espécies são predominantemente autogamas (HEISER \& SMITH, 1953; GOVINDARAJAN, 1985). A taxa de polinização cruzada é variavel, podendo ser tão baixa 
quanto $0,5 \%$ ou atingir valores como $36 \%$ (CASALI et a l., 1984). A polinização cruzada natural é devida primariamente ao vento e a insetos (GOVINDARAJAN, 1985). A autoincompatibilidade já foi registrada em algumas espécies selvagens, enquanto que em outras a presença de estiletes grandes permite a polinização cruzada (HEISER \& SMITH, 1953).

Todas as espécies cultivadas de Capsicum, bem como as selvagens, são diploides $(2 n=2 x=24)$. C.pubescens parece estar isolada geneticamente das outras espécies cultivadas. Combinações hf bridas entre as outras quatro espécies têm sido obtidas, com graus variáveis de fertilidade, assim como entre espécies cultivadas e selvagens (HEISER \& SMITH, 1953; GOVINDARAJAN, 1985).

O pimentão, amplamente utilizado no estadio imaturo ou verde na forma de salada ou recheado, é mais apreciado em zonas temperadas do que nos tropicos. Seu conteudo nutricional é relativamente alto e são boas fontes de vitaminas, particularmente vitamina $c$, $e$ os tipos pungentes desidratados são ricos em vitamina A.

\subsection{Murcha do Pimentão}

\subsubsection{Sint oma tologia}

Nas solanaceas, a doença manifesta-se desde a sementeira até a planta adulta. As plântulas quando atacadas sofrem murcha da parte aérea em consequência da morte das rarzes e necrose do colo, tombando logo em seguida. Em condições de campo, a doença distribui-se em reboleira, tendo como sintoma caracterfstico murcha repentina, necrose de cor marrom no coleto e seca da planta (SALGADO \& TOKESHI, 1980; MATSUOKA \& ANSANI, 1984; POLTRONIERE, 1986). Em época chuvosa, o ataque pode iniciar-se pela parte aérea da planta. Os sintomas nos ramos são semelhantes aos do colo, ou seja, 
necrose de tamanho variável circundando todo o caule, provocando murcha, amarelecimento e queda das folhas. As folhas atacadas apresentam lesōes encharcadas, verde-escuras com limite definido, que depois expandem-se tornando-se amarronzadas e caem (MATSUOKA \& ANSANI, 1984). Os frutos tendem a mumificar, tornando-se quase negros, enrrugados, inodoros e presos ao caule, mostrando nftida separação entre tecidos doentes e sadios (SALGADO \& TOKESHI, 1980).

\subsubsection{Epidemiologia}

O principal agente de disseminação da murcha-defitoftora do pimentão é a água de irrigação ou chuva, sendo que a sobrevivência do patogeno é maior em solo contendo entre 18 e $34 \%$ de umidade (RAMIREZ \& COVA, 1980; ANSANI \& MATSUOKA, 1982). A dispersão da doença na parte aérea pode ocorrer por meio de respingos de agua, pelo contato direto entre os hospedeiros na parte aérea, por insetos ou por fatores mecânicos (DUNIWAY, 1987 ; WESTE, 1987 ).

A sobrevivência de oosporos no solo é bem maior do que a de micélio (RAMIREZ \& COVAS, 1980). Esta sobrevivência foi atribuída à liberação de oosporos pela decomposição de tecidos infectados, já que estas estruturas podem permanecer viáveis por cerca de 200 a 240 dias no solo (ANSANI \& MATSUOKA, 1983a). Os zoosporos têm baixa capacidade competitiva, não sobrevivem nem $70 \mathrm{dias}$ no solo, enquanto que o micélio e os esporângios permanecem menos do que 120 dias em fragmentos de hipocotilo e raiz enterrados no solo (ANSANI \& MATSUOKA, $1983 \mathrm{~b}$ ).

Em relação a sobrevivência em sementes infectadas, observou-se que estas não geram plântulas infectadas, mas a germinação é severamente afetada (MAFFIA \& MATSUOKA, 1982). Dois dias apos a remoção das sementes do fruto infectado, foi encontrado micélio e obsporos no tegumento, endosperma e embrião. Apos cinco dias em condições 
de laboratorio, a recuperação do fungo foi quase nula e não se detectou o patógeno em sementes armazenadas por cinco dias em dessecadores (MAFFIA \& MATSUKA, 1982).

Além de pimenta e pimentão, P.capsici é patogênico a diversas culturas, como tomate, abobora, morango, melão, melancia, pepino, ervilha, berinjela, cenoura e ji 10 (URBEN, 1980; REGO \& REIFSCHNEIDER, 1982; POLTRONIERI, $1986)$.

\subsubsection{Et iologia}

Em 1922, LEONIAN relatou pela primeira vez o fungo Phytophthora capsici como o agente etiologico da murcha ou requeima do pimentão.

P.capsici pertence à Divisão Eumycota, Sub-divisão Mastigomycotina, Classe Oomycetes e Ordem Peronosporales (Silveira, 1981, citado por Costa, 1987).

A forma do esporângio pode ser sub-esférica, oval, oboval, elf ptica, fusiforme, piriforme ou alongada (ALIZADEH \& TSAO, 1984), medindo em média $60 \times 36$ pm (WATERHOUSE, 1970).Os esporângios desprendem-se facilmente quando maduros (ALIZADEH \& TSAO, 1984) e são responsáveis pela produção de zoosporos, os principais agentes infectivos do fungo (WESTE, 1987). Os clamidosporos, quando produzidos, são relativamente pequenos $(28-29 \mu \mathrm{m}$ de diâmetro), com parede celular de $2,4-2,7$ um.

$P$. capsici é um fungo de natureza heterotálica, caracterizada através dos grupos de compatibilidade $A_{1}$ e $A_{2}$ Substâncias presentes no meio de cultura podem influenciar a produção de oosporos em cruzamentos intraespecfficos de P.capsici, como suco V-8 e suco de tomate "Superbom" temperado (URBEN, 1980). Os obsporos são esféricos, com diâmetro de $22-37 \mu \mathrm{m}$. No gametângio o ntmero de cromossomos é $\mathrm{n}=8-12$ (ALIZADEH \& TSAO, 1984).

A temperatura mínima para o crescimento do 
fungo em cultura é de $6-9^{0} \mathrm{C}$, a btima fica em torno de 27 $30^{\circ} \mathrm{C}$ e a máxima de $33-39^{\circ} \mathrm{C}$ (ALIZADEH \& TSAO, 1984). A temperatura para a formação de esporângios situa-se entre 21 - $33^{\circ} \mathrm{C}$, e a otima de $24-27^{\circ} \mathrm{C}$ (RIBEIRO, 1987 ).

Há relatos da existência de estirpes de P.capsici para determinados hospedeiros (POLACH \& WEBSTER, 1972 ; KUNIMOTO et al., 1976). No entanto, URBEN (1980) e SARAIVA (1982) não encontraram especificidade ou diferenças de patogenicidade. Em Minas Gerais não foi constatada a ocorrência de estirpes ou raças de P.capsici que se comportassem diferentemente (MATSUOKA, 1984).

\subsubsection{Controle}

O controle da doença é diffcil depois que o patogeno se estabelece no solo, onde sobrevive por longos perfodos (ANSANI \& MATSUOKA, 1982).

Uma das estratégias de controle baseia-se no emprego de fungicidas especificos para Ficomicetos (Papavizas \& Bower, 1982, citados por FERNÁNDEZ, 1988). Encontra-se no mercado a mistura Metalaxyl-Mancozeb, especffica para o controle de Phytophthora e Pythium, que tem proporcionado bons resultados nos testes em pimentão, embora não tenha sido registrada para esta cultura (ANSAN \& MATSUOKA, 1982).

O Metalaxyl é um fungicida sistêmico ativo especialmente contra membros dos Oomycetos, como Phytophthora spp. Este fungicida tem se mostrado altamente efetivo contra a murcha-de-fitoftora do pimentão pela inibição do crescimento micelial, germinação de zoosporos, liberação de zoosporos do esporângio e formação de esporângios, ainda que em baixas concentrações (BUYNG et al., 1990).

O controle qứmico é eficiente, porém de custo elevado e indutor de mudanças na composição genética do fungo. Foram encontrados biotipos de P.capsici resistentes a Metalaxyl (Reifschneider, 1982, citado por CosTA, 1987). 
A maneira mais efetiva e segura de se controlar $P$. capsici é o uso de cultivares com resistência genëtica (MATSUOXA \& ANSANI, 1984; FERNANDEZ, 1988; BOSLAND \& LINDSEY, 1991$)$.

2.3. Res is tência

2.3.1. Fontes de Resistência

Em 1960, KIMBLE \& GROGAN avaliaram 613 variedades de pimenta, todas compativeis com $C$. annuum. Verificaramque cinco destas (PI 187331, PI 123469, PI 201232, PI 188476 e PI 201234 ) apresentaram alto grau de resistência, tendo sobrevivido um maior numero de plantas de PI 201234. Na avaliação feita por SEGURA (1962), de 129 variedades de Capsicum spp. testadas, os genotipos 631-A Marinalco do México, PI 201232 e PI 201234 (KIMBLE \& GROGAN, 1960) e o máterial peruano "Mishime Bravo Amarilla" (C. pendulum), comportaram-se como totalmente resistentes. Enquanto que PI 201235 e PI 159233 (California) e a variedade peruana Rocoto (C. pubescens) mostraram-se altamente resistentes.

De acordo com as avaliações de SOTIROVA et al. (1977), duas variedades, Mulato e Bogilszlo, mostraram-se totalmente resistentes.

Dentre os materias avaliados por Redondo (1975), destacaram-se os tipos "serranos" (C. annuum) conhecidos no México como "Criollo de Morelos" (CM), com nf veis de resistência que variaram de 44 a 100\% (ORTEGA \& ESPAÑOL, 1982). A linha CM 334 nas avaliaçoes de Redondo (1979) apresentou $100 \%$ de resistência (ORTEGA \& ESPAÑOL, $1982)$.

No Brasil, MATSUOKA et al. (1984) avaliaram 396 introduções de Capsicum do Banco de Germoplasma de Hortaliças (BGH) da Universidade Federal de Viçosa. Foram selecionadas cinco fontes de resistência a $P$. capsici, 
oriundas das introduções BGH 176, BGH 2678, BGH 3032, BGH 3036 e BGH 3056. Todas pertencem a C. annuum e são do tipo pimenta.

BANJA (1989) descreveu uma introdução de pimenta ornamental picante como resistente. Apesar de apresentar as folhas basais amarelecidas, as plantas não mostraram sintomas de murcha. LOTZ \& COSTA (1991) trabalharam com uma fonte de resistência pertencente a espécie $C$. chinense.

\subsubsection{Herança da Resistência}

O conhecimento do fator genético da resistência é importante no desenvolvimento de cultivares resistentes. Existem muitas divergências entre os trabalhos de pesquisa quanto ao controle genético da resistência de Capsicum spp. a P. capsici.

SMITH et al. (1967) estudaram a herança da resistência das linhagens PI 123469, PI 201232 e PI 201264 (Kimble \& Grogan, 1960), juntamente com a cultivar suscetfvel Yolo Wonder. Sugeriram que a resistência é governada por 2 genes, que agem independentemente, conferindo a 1 to ni vel de resistência aos materiais, mas não resistência total ao patogeno. SOLANES \& LOTTI (1967) utilizando as mesmas introduções norte-americanas e cultivares da Argentina, França e Romênia, descreveram a resistência como sendo um carater dominante. As linhas de Smith et al (1967) foram avaliadas juntamente com um material francês por YAMAKAWA et al. (1979), que concluiram tratar-se de uma herança monogênica, com dominância incompleta.

Dos materiais testados por GUERRERO-MORENO \& LABORDE ( 1980 ) apenas dois comportaram-se como totalmente resistentes, sendo sugerido que a resistência é controlada por dois pares de genes recessivos e independentes. Para SARAIVA (1982), que trabalhou com as linhagens BGH 176 
(Santaka), BGH 2678 (Floral Gem), BGH 3232 (Chiroleze), BGH 3036 (Cubano Amarillo) e BGH 3056 (Mirasol), trata-se de uma herança recessiva (dois genes), influenciada por um gene modificador dominante.

A resistência em duas linhagens derivadas das variedades coreanas "Gimjorggochu" e "Shinpyong", é governada por um ou dois pares de genes dominantes (CHOI et al., 1984), enquanto que BARKSDALE et a l. (1984) constataram que a resistência, nas duas fontes que trabalharam, é determinada por um par de genes com modificadores.

BANJA (1989), utilizando uma introdução de pimenta ornamental picante, LOTZ \& COSTA (1991) uma 1 inhagem de $C$. chinense e REIfSCHNEIDER et al. (1992) uma linha derivada de $C M 334$, conclup ram que a resistência é controlada por dois genes, com epistasia dominante e recessiva. Os resultados obtidos por CRISTINZIO et al. (1992) sugerem que a resistência a $P$. capsici na linha CM 334 é devido a dois pares de genes dominantes.

A caracterização da resistência em $C$. frutescens L. sugere que o controle éfeito por um unico gene dominante, enquanto que para Saini \& Rattan (1971) trata-se de um gene recessivo (ZEMA et al., 1992).

ORTEGA et al. (1992) estudaram a relação entre quatro genbtipos de pimenta resistentes a P.capsici, onde a resistência está sob o controle de 3 genes. Os quatro materiais parecem ter em comum ao menos um dos três genes postulados para o carater em questão.

Embora a maioria dos trabalhos tenha descrito que um ou dois genes são responsaveis pela resistência a $P$.capsici, praticas de melhoramento demonstram que a herança do caráter é um pouco mais complexa. E provável que a resistência esteja sob controle poligênico e dividida em varios componentes genéticos, distribufdos de forma desigual entre as variedades (ORTEGA \& ESPAÑOL, 1982; POCHARD \& DAUBEZE, 1982; PALLOIX et a 1., 1990). 
2.3.3. Mel horamento

A introdução da resistência a P.capsici em cultivares de pimentão através do método de retrocruzamento não tem tido sucesso. Na Argentina foi desenvolvida a "linha n2 10" a partir da linha 491 de Smith et al. (1967) (SOLANES \& LOTTI, 1970). A linha "PM 217" selecionada do material 493-1 (Smith et al., 1967) foi retrocruzada com a cultivar Yolo Wonder dando origem a linha "Phyo 636" (POCHARD \& CHAMBONNET, 1971). A resistência da linha 493 também foi transferida a cultivar Yolo Wonder por ORTEGA \& ESPAÑOL (1982), que a denominaram de "linha ne 2". Estas variedades têm mostrado um nível baixo de resistência quando comparadas com os parentais resistentes (ORTEGA \& ESPAÑOL, 1983; PALLOIX et a 1., 1988b; PALLOIX et a 1., 1990; BARTUAL et a 1., 1991).

A cultivar norte-americana "Vi deo", tida como zosistente, apresenta $8,9 \%$ de incidência de doença, enquanto que a cv. "Lady Bell" (moderadamente resistente) apresenta $22,2 \%$ (JOHNSTON \& BARKSDALE, 1987). Um bom nível de resistência e produção foi obtido em duas cultivares de pimenta doce na Costa Rica, "Najera 2" e "172248" (JIMENEZ et a 1., 1990).

A linha mexicana CM 334 foi cruzada com a cultivar "Friariello" (C.annuum) e os resultados sugerem que a resistência é facilmente introduzida (CRISTINZIO et al., 1992 ).

o insucesso na obtenção de cultivares de pimentão resistentes a P.capsici pode ser explicado pelo controle poligênico deste caráter (POCHARD \& DAUBEZE, 1982; PALLOIX et al., 1990) e pela ausência de critérios adequados de seleção (ORTEGA \& ESPAÑOL, 1983; REIFSCHNEIDER et al., 1986b). O método de seleção recorrente parece ser o mais apropriado para este caso. PALLOIX et al. (1990), através de dois ciclos de seleção recorrente, obtiveram algumas linhas que mostraram um nível de resistência superior ao dos 
parentais resistentes da população original, apesar desse progresso ter se mostrado irregular. Houve uma forte influência das condições ambientais durante a execução da seleção e avaliação dos materiais. Isto vem a comprovar a hipotese de ORTEGA \& ESPAÑOL (1982) de que a resistência é horizontal com alguns aspectos de resistência vertical, que podera se manifestar de acordo com as circunstancias em que é feita a seleção. Assim, os genes de maior efeito na expressão da resistencia são selecionados quase que independentemente do critério ou método de seleção utilizado, enquanto que genes de menor efeito, que provavelmente melhoram a ação de genes maiores, são ma is diff́ce is de serem selecionados (ORTEGA \& ESPAÑOL, 1983).

\subsubsection{Influência de Fatores Ambientais}

\subsubsection{Idade da Planta}

São varios os relatos sobre a quebra da resistencia em genotipos de pimenta e pimentão devido a Enoculação em plantas em idade jovem (REIFSCHNEIDER et al., 1986b). Alguns pesquisadores acreditam que a suscetibilidade de mudas de pimentão a P.capsici não é influenciada pela idade, embora a murcha ocorra mais rapidamente em plantas ma is jovens. O desenvolvimento da doença em plântulas é mais rapido provavelmente devido a áreas menores de rafzes e hipocotilos a serem colonizadas pelo patogeno, até que a planta entre em colapso total (ANSANI \& MATSUOKA, 1983c; FERNANDEZ, 1983).

Com o objetivo de identificar fontes de resistência na fase juvenil a P.capsici em Capsicum, foram avaliados vários genotipos do Banco At ivo de Germoplasma (BAG) e Pimenta e Pimentão do CNPH/EMBRAPA. Destacaram-se dois materiais, CNPH 148 e CNPH 173 , dentro de populações que apresentaram melhor desempenho na fase adulta (CAFE-FILHO \& 
REIFSCHNEIDER, 1986). Inoculações precoces aumentaram o numero de plantas com reação de suscetibilidade, em todos os genotipos testados. A resistência aumentou com a idade cronologica até 40-47 dias, quando CNPH 148 e CNPH 173 comportaram-se como totalmente resistentes (CAFE-FILHO \& REIFSCHNEIDER, 1986). Foi sugerido que plantas de pimenta são resistentes a partir do estadio de seis folhas (POCHARD\& CHAMBONNET, 1971) e 40 dias apos a semeadura (POCHARD et al., 1976 ).

BOSLAND \& LINDSEY (1991) verificaram que é possfuel selecionar plantas de pimentão com 14 dias apos a emergência para resistência a podridão de raiz, causada por P. capsici.

As idades das plantas na data de inoculação são bem variaveis, e sabemos que fatores ambientais exercem forte influência sobre o desenvolvimento da planta, tornando diffcil o estabelecimento de uma correlação entre idade cronologica e estádio de desenvolvimento. Até o momento não foi possf vel avaliar a idade fisiologica de uma planta e isto deverá ser essencial para estabelecer procedimentos para a detecção de resistência em plântulas (REIFSCHNEIDER et al., $1986 b)$.

\subsubsection{Métodos de Inoculação}

O método de i noculação adotado por KIMBLE \& GROGAN (1960) e SEGURA (1962) consistiu na infecção de bandejas, onde estavam sendo cultivadas as plantas, com suspensãomicelial. Os melhores materiais foram reinoculados, so que desta vez com suspensão de zoosporos. SMITH et al. $(1967)$ e POLACH \& WEBSTER (1972) colocaram a suspensão micelial diretamente nas rafzes das plantas.

POCHARD \& CHAMBONNET (1971) usando diferentes métodos de inoculação, determinaram como melhor a aplicação de um "plug" de micélio sobre o caule decapitado. CLEARJEAU 
et a 1. (1976) chegaram à mesma conclusão quando testaram o método de POCHARD \& CHAMBONNET (1971), em conjunto com inoculações em folhas destacadas e incorporação de inoculo no solo.

SOTIROVA et al. (1977) conduziram seus experimentos em condições de campo naturalmente infectado e em casa-de-vegetação, onde a inoculação foi feita mediante a pulverização das folhas com suspensão de zoosporos. Os fndices de infecção em casa-de-vegetação foram maiores,provavelmente devido a condições otimas ao desenvolvimento do patogeno. A inoculação foliar tem se mostrado inapropriada para seleções mais precisas (CLEARJEAU et al., 1976; KIM et al., 1989), além de que os fatores genéticos que governam a resistência em ralzes e caule podem não ser operáveis em folhas (KIM et al., 1989).

o estudo sobre métodos de inoculação feito por REIFSCHNEIDER et al. (1986a) mostrou que somente quando a suspensão de zoosporos é aplicada na base da planta ou quando as rafzes são imersas na suspensão, todas as plantas morrem. Entre as metodologias testadas por KIM et al. (1989) para a avaliação da resistência relacionada a idade, a inoculação de suspensão de zobsporos no solo foi a mais eficiente. Para POCHARD \& CHAMBONNET (1971) e KHAN et al. (1992) a inoculação de suspensão de zobsporos na base da planta pareceu pouco efetiva, uma vez que resultou em escapes de plantas suscetílveis e infecção e morte de resistentes. A concentração de inocu lo (CLEARJEAU et a l., 1976; REIFSCHNEIDER et a l., 1986a) assim como a umidade do solo são de vital importância para a eficácia deste método (REIFSCHNEIDER et a 1., 1986a). Para KHAN et al. (1992) a imersão de rafzes em suspensão de zoosporos mostrou-se o método de inoculação mais adequado, a lém de ser simples de se manusear e rápido.

A técnica de inoculação usando zoosporos é melhor do que o uso de micélio, por estar estreitamente relacionada a condição natural e ser fácil de quantificar, 
a lém dos zoosporos serem facilmente obtidos (URBEN, 1980; REIFSCHNEIDER et a l., 1986a; BOSLAND \& LINDSEY, 1991).

\section{$2 \cdot 3 \cdot 4 \cdot 3$. I so I ados}

A capacidade de P.capsici superar a resistência de plantas de pimenta é controlada pelo menos por dois pares de genes (POLACH \& WEBSTER, 1972). A variabilidade na virulência pode ocorrer devido a trocas nucleares através da recombinação sexual, baseada em dois tipos de compatibilidade designados de $A_{1}$ e $A_{2}$ (KIM \& HUANG, 1992). Foi demonstrado que ossporos obtidos de pareamentos entre isolados patogênicos diferiram em sua capacidade de causar doença em plantas de pimenta (BOWERS \& MITCHELL, 1991). Em adição a recombinação sexual, a manutenção de culturas de Phytophthora spp. in vitro por longo tempo pode causar variações em sua virulência (KIM \& HUANG, 1992).

A presença de biotipos muito virulentos pode superar a resistência de Capsicumspp. a P.capsici em testes de inoculação artificial, bem como em condições de campo (ORTEGA \& ESPAÑOL, 1983; BARKSDALE et al., 1984; REIFSCHNEIDER et a 1., 1986b; PALLOIX et a 1, , 1988a).

Algumas 1 inhas $t$ idas como resistentes, como "Phyo 636" (ClearjeaU et al., 1976), "235" e "493" (SMITH et al., 1967) mostraram-se suscetífeis a alguns biotipos de P.capsici (POLACH \& WEBSTER, 1972; ORTEGA \& ESPAÑOL, 1982).

A agressividade de doze isolados de P.capsici da Turquia foi comparada em duas linhas de pimenta parcialmente resistentes, "PM 217" e "Serrano Criollo de Morelos" (ABAK \& POCHARD, 1984). Todos isolados turcos mostraram-se virulentos e a maioria deles foi muito agressiva, principalmente sobre a linha "PM 217". Nenhuma diferença significativa foi observada sobre a linha "Serrano Criollo de Morelos".

Os isolados de P.capsici revelam-se mais 
agressivos em temperaturas mais altas, principalmente em variedades suscetiveis. As variedades resistentes e parcialmente resistentes não se mostram afetadas pela temperatura (ORTEGA et a l., 1984a).

\subsubsection{Concentração de Inoculo}

Concentrações de inoculo muito altas de P.capsici podem superar ocasionalmente a resistência em Capsicum, resultando em sintomas em plantas consideradas resistentes (BARKSDALE et a ., 1984; REIFSCHNEIDER et a l., 1986b). Além da concentração de inoculo, o período de incubação tambem parece afetar grandemente a expressão de resistência em plantas de pimenta (SMITH et al., 1967; BARKSDALE et a l., 1984). O tempo de saturação do solo é de suma importância para a produção e movimentação de zoosporos de P.citrophthora e P.parasitica (Stolzy et al., 1965, citados por ANSANI \& MATSUOKA, 1983a).

Em testes feitos em casa-de-vegetação foi verificado que a concentração $10^{4}$ zoosporos por planta foi suficiente para matar todas as plantas suscetiveis (ANSANI \& MATSUOKA, 1983c; REIFSCHNEIDER et a 1, 1986b; BOSLAND \& LINDSEY, 1991). A concentração $5 \times 10^{3}$ zoosporos por planta matou apenas um terço do genotipo suscetíl vel (ORTEGA et al., 1984b). Em condições de campo $10^{5}$ zobsporos por planta é considerada uma concentração ideal (REIFSCHNEIDER et a., $1986 \mathrm{~b})$.

As concentrações LD 50 para as variedades resistentes são altamente variáveis, 4385 a 97300 zoosporos para o isolado menos virulento (PALloIX et a l., 1988b). Essas concentrações são menores do que as indicadas anteriormente, provavelmente devido ao método de inoculação em meio líquido utilizado, que aumenta o contato raiz-zoosporos. No método de infestação do solo, muitos zoosporos não infectam as raizes 
e encistam sobre particulas de solo, diminuindo a infectividade do esporo (PALLOIX et al., 1988b).

Os resultados podem ser influenciados por altos nf́eis de inoculo, que podem não ser representativos da relação infeç̧ão-inoculo que ocorre no campo. Baixos níveis de inoculo, tanto de zobsporos como obsporos, podem afetar a incidência de doença no campo, sob condições apropriadas (BOWERS \& MITCHELL, 1991).

\section{$2 \cdot 3 \cdot 4 \cdot 5$. Temperatura}

A expressão da resistência de C.annuum a P.capsici parece instavel, uma vez que variou também com a temperatura (CLEARJEAU et al., 1976; POCHARD et al., 1976). Em materiais tidos como resistentes o fungo continuou o seu crescimento a $28{ }^{\circ} \mathrm{C}$, o mesmo não foi observado a $22{ }^{\circ} \mathrm{C}$ (POCHARD et a l., 1976). A cultivar "Phyo 636" mostrou-se ma is resistente em temperaturas mais baixas $\left(19 \pm 3^{\circ} \mathrm{C}\right)$ do que em altas $\left(25,7 \pm 3^{\circ} \mathrm{C}\right)$ (ORTEGA \& ESPAÑOL, 1984a).

Quanto maior a resistência das linhas testadas, mais independente foi a sua resposta aos efeitos de temperatura; em linhas suscetfveis o parasita foi mais agressivo na temperatura elevada $\left(25,7 \pm 3^{\circ} \mathrm{C}\right)$ do que na temperatura baixa $\left(18,8 \pm 2,9^{\circ} \mathrm{C}\right)$ testadas (ORTEGA \& ESPAÑOL, 1983; ORTEGA et al., 1984a). A diferenciação entre plantas suscetf veis e resistentes foi melhor nas temperaturas maxima de $25,7 \pm 3^{\circ} \mathrm{C}$ e minima de $15,9^{\circ} 3^{\circ} \mathrm{C}$ (ORTEGA et al., 1987). Aconselha-se que as inoculações de P.capsici em Capsicum sejam executadas sob temperaturas moderamente altas (ORTEGA \& ESPAÑOL, 1983). 
3. MATERIAL E METODOS

Os experimentos foram conduzidos em casa-devegetação e no laboratorio de Fitopatologia do centro Nacional de Pesquisa de Hortaliças (CNPH / EMBRAPA).

\subsection{Instalação dos Experimentos}

\subsubsection{Casa-de-vegetação}

O substrato utilizado para cultivar as plantas foi obtido através de uma mistura de solo peneirado, esterco de gado e palha de arroz queimada, na proporção de 3:1:1, e adubo químico $\mathrm{N}-\mathrm{P}-\mathrm{K}$, formula 4-14-8. A mistura foi esterilizada com brometo de metila na dosagem de 50 cc para 1001 itros de substrato.

Para obter uma germinação uniforme, as sementes foram tratadas com uma solução de $0,2 \%$ de $\mathrm{KNO}_{\mathfrak{j}}$. A semeadura foi feita em caixas de plástico $(40 \times 30 \times 10 \mathrm{~cm})$ contendo o substrato esterilizado.

As plantas foram mantidas até a véspera da inoculação em uma casa-de-vegetação com temperatura média de $27{ }^{\circ} \mathrm{C}$. A inoculação foi feita em outra casa-de-vegetação, com $\mathrm{t} \max .=26^{\circ} \mathrm{C}$ e $\mathrm{t} \mathrm{min}=16^{\circ} \mathrm{C}$.

Os genotipos uti lizados pertencem a coleção de Germoplasma de Capsicum do CNPH. Como padrões de resistência foram utilizados CNPH 148, uma linha derivada do genotipo "Serrano Criollo de Morelos 334" (CM 334); e CNPH 173, selecionada da população BGH 3036 da Universidade Federal de 
Viçosa-MG. Os dois materiais são do tipo pimenta e pertencem a espécie C.annuum. A linha CNPH 173 possui um nível menor de resistência a P.capsici do que a linha CNPH 148, mas apresenta como vantagem o fato de ser menos pungente e fruto do tipo pimentão. Como padrão suscetílel foi utilizado o genotipo CNPH 192, a cultivar comercial "Magda" (Agroflora).

\subsubsection{Produção de Inoculo}

O isolado 2 de P.capsici utilizado nos experimentos pertence a Coleção do CNPH/EMBRAPA, e foi escolhido por apresentar um bom nível de virulência e boa esporulação em meio de cultura (REIFSCHNEIDER et al., 1986). O isolado foi mantido e periodicamente repicado para tubo de ensaio contendo meio de cultura batata-dextrose-agar (BDA). Para o preparo de inoculo, o fungo foi repicado para placas de Petri contendo BDA, e incubadas a $27^{\circ} \mathrm{C}$, no escuro, durante 4 a 6 dias. Em seguida, foram retirados pequenos discos de micélio do fungo, e colocados individualmente no centro de cada placa de petri com meio de suco de tomate-agar $(200 \mathrm{ml}$ de suco de tomate temperado "Superbom", $3 \mathrm{~g} \mathrm{de} \mathrm{CaCO}_{3}, 18 \mathrm{~g} \mathrm{de}$ agar e $800 \mathrm{ml}$ de agua destiladal. As placas foram mantidas por 6 das a $22-24^{\circ} \mathrm{C}$ sob luz fluorescente para estimular a esporulação. Apos esse perfodo, foram adicionados $10 \mathrm{ml}$ de agua por placa de petri e deixadas por 2 horas a $4^{\circ} \mathrm{C}$ (REIFSCHNEIDER et a 1., 1986b). As placas permaneceram por mais uma hora em temperatura ambiente, para a liberação de zobsporos pelos zoosporângios. Com o auxi lio de uma alça de Drigalsky, a superffcie do meio foi raspada e a suspensão fi l trada através de uma camada dupla de gaze, para reter os fragmentos de micélio.

A concentração de inoculo foi ajustada com o auxílio de um hemacitômetro. 
3.1.3. Método de Inoculação e de Avaliação

Antes da inoculação, as caixas contendo as plântulas foram irrigadas até a saturação do solo e posteriormente duas vezes ao dia. O método de inoculação adotado foi a deposição de $3 \mathrm{ml}$ de uma suspensão zoosporos na altura do colo da planta, sem molhar o caule (REIFSCHNEIDER et al., 1986b).

As avaliações foram feitas no 49 e 89 dias apos a inoculação, através da contagem do numero de plantas tombadas. As reações de suscetibilidade observadas foram caracterizadas pela necrose na base do caule (colo) e murcha, que culminaram com o tombamento das plântulas.

3.2. Padronização do Método de Avaliação para Resistência Juveni 1

Este experimento visou estudar os efeitos de fatores ambientais na expressão de resistência a P.capsici, em genotipos de C.annuum, e determinar as condições ideais para avaliar a resistência no estadio de plântulas, evitando-se escapes.

\subsubsection{Efeito da Data de Avaliação apos a Inoculação}

Este ensaio preliminar foi conduzido em casa-de-vegetação, com temperatura média de $26^{\circ} \mathrm{C}$ o aparecimento de sintomas e desenvolvimento da doença foram avaliados diariamente até 0169 dia apos a inoculação, em plantas com 10,15 e 20 dias apos a emergência. Foram utilizados 11 genotipos, incluindo CNPH 148 , CNPH 173 e CNPH 192. Em cada caixa foram semeadas quatro fileiras, com sete plantas por fileira. Cada planta foi inoculada com $3 \mathrm{ml}$ de suspensão de $10^{4}$ zoosporos/ml (REIFSCHNEIDER et al., 1986b) na altura do colo. O desenvolvimento da doença foi avaliado separadamente para cada idade testada. 
O delineamento experimental empregado foi inteiramente casualizado, com os tratamentos em fatorial $11 \times 16$ e três repetições ( 7 plantas/repetição).

\subsubsection{Efeito da Concentração de Inoculo}

o objetivo deste experimento foi redefinir a concentração de inoculo mais adequada do isolado de $P$. capsici CNPH 2, para avaliação de resistência juvenil em condição de casa-de-vegetação .

Em um primeiro ensaio foram testadas as seguintes doses : $5 \times 10^{2} ; 10^{3} ; 5 \times 10^{3} ; 10^{4}$ e $5 \times 10^{4}$ zoosporos/ml, nos genotipos CNPH 173 e CNPH 192. O genotipo CNPH 148 (padrão de resistência) teve a sua germinação comrrometida, e não participou deste ensaio. As plantas foram inoculadas com 15 dias apos a emergência, com $3 \mathrm{ml}$ de suspensão de inoculo, na altura do colo. A temperatura média durante a execução do experimento foi de $29,5^{\circ} \mathrm{C}\left(\max .=39^{\circ} \mathrm{C}\right.$; $\mathrm{m}\left(\mathrm{n} .=20^{\circ} \mathrm{C}\right)$.

Dois outros ensaios foram montados:

1. Plantas dos genotipos CNPH 148, CNPH 173 e CNPH 192, com 7 dias apos emergência, foram inoculadas com suspensões de $5 \times 10^{4}, 10^{5}$ e 5 × $10^{5}$ zoosporos/ml (3 $\mathrm{ml} / \mathrm{planta})$.

2. Foram testadas duas concentrações, $5 \times 10^{4}$ e $10^{f}$ zoosporos/ml, em plantas com 15 dias apos a emergência ( $3 \mathrm{ml} / \mathrm{planta}$ ). A temperatura média maxima foi de $26^{\circ} \mathrm{C}$ e a minima de $16^{\circ} \mathrm{C}$.

O delineamento experimental adotado foi blocos casualizados com parcelas subdivididas, com quatro repetições. Os tratamentos principais foram as concentrações de inoculo e os secundarios foram os genotipos. Cada parcela foi composta por uma caixa de plastico, contendo três fileiras (subparcelas) com 7 plantas de cada um dos genotipos. 
3.2.3. Efeito da Idade da Planta

Em casa-de-vegetação com temperatura média diurna de $23,5^{\circ} \mathrm{C}$ e noturna de $16,5^{\circ} \mathrm{C}$, plântulas dos genotipos CNPH 148, CNPH 173 e CNPH 192, com 10, 15, 20 e 25 dias apos a emergência, foram inoculadas inicialmente com uma suspensão de $10^{4}$ zoosporos/ml do isolado $\mathrm{CNPH} 2$.

Posteriormente foi montado outro ensaio, com plantas com 7 e 14 dias apos a emergência, utilizando-se concentraçao de inoculo $5 \times 10^{4}$ zoosporos/ml. As temperaturas médias maxima e mı́nima no perfodo foram respect ivamente, 26 e $16^{\circ} \mathrm{C}$.

O delineamento experimental adotado foi blocos casualizados com parcelas subdivididas, com quatro repetiçóes. Os tratamentos principais foram idades na época de inoculação e os secundarios foram os genotipos. Cada parcela constou de uma caixa de plastico, com três fileiras (subparcelas) com 7 plantas de cada um dos genotipos.

Ainda neste experimento, plantas dos genot ipos $\mathrm{CNPH} 148, \mathrm{CNPH} 173$ e $\mathrm{CNPH} 192, \mathrm{com} 7,14,21,28$ e 35 dias apos a emergência, cultivadas em vasos de meio litro ( 1 planta/vaso), foram inoculadas com $20 \mathrm{ml}$ de uma suspensão de $5 \times 10^{4}$ zoosporos/ml. A finalidade deste ensaio foi observar o comportamento dos três genotipos citados anteriormente, quanto ao nf vel resistência a $P$. capsici, do estadio juvenil até a fase adulta da planta. O experimento seguiu um delineamento em blocos casualizados com parcelas subdivididas, com 4 repetições. Os tratamentos principais foram idades da planta e os secundarios genotipos. As parcelas foram compostas por 15 vasos, sendo cinco vasos de cada genotipo uma subparcela.

\subsubsection{Efeito da Temperatura}

O ensaio foi conduzido em dois ambientes, com 
temperatura e umidade monitoradas, um com temperatura mais baixa $\left(\mathrm{t} \max =27,5^{\circ} \mathrm{C} ; \mathrm{t} m \mathrm{~m}=17,7^{\circ} \mathrm{C}\right)$, e outro com temperatura mais alta $\left(\mathrm{t} \max =39^{\circ} \mathrm{C} ; \mathrm{t}\right.$ mi $\left.\mathrm{n}_{0}=20,4^{\circ} \mathrm{C}\right) \cdot \mathrm{A}$ concentração de inoculo utilizada foi $10^{4}$ zoosporos $/ \mathrm{ml}$. Plantas dos genótipos CNPH 148, CNPH 173 e CNPH 192 foram inoculadas com 10 e 15 dias apos a emergência.

Foi montado um segundo ensaio aumentando-se a concentração de inoculo para $5 \times 10^{4}$ zoosporos/ml. No ambiente com temperatura mais alta, a média maxima foi de $38,7^{\circ} \mathrm{C}$ e a mínima de $20,8^{\circ} \mathrm{C}$, enquanto que no ambiente com temperatura ma is baixa, a média maxima foi de $26,3^{\circ} \mathrm{C}$ e a mínima de $15,9^{\circ} \mathrm{C}$. Plantas dos genotipos CNPH $148, \mathrm{CNPH} 173$ e CNPH 192 foram inoculadas com 7 e 14 dias apos a emergência.

o delineamento experimental foi blocos casual izados com parcelas subdivididas, com 4 repetições. Os tratamentos principais foram idades da planta na epoca de inoculação e os secundarios genotipos. As parcelas foram compostas por caixas de plastico, contendo três fileiras cada (subparcelas), com 7 plantas de cada genotipo.

\subsection{Araliação da Resistência de Genotipos do BAG de Capsicum do CNPH à Phytophthora}

A coleção de Germoplasma de Capsicum do CNPH/EMBRAPA conta atualmente com cerca de 400 introduções, tanto do Brasil como de outros par ses da América do Sul e Central, Ásia e Europa.

Para a identificação de novas fontes de resistência na fase juvenil a P.capsici foram avaliados, em condição de casa-de-vegetação, 80 populações de Capsicum spp., em 5 experimentos.

Os materiais avaliados, assim como suas procedências estão relacionados na tabela 01 . O delineamento experimental adotado foi inteiramente casualizado, com quatro repetições $(7$ plantas/repetição). 
A inoculação foi feita através da deposição de $3 \mathrm{ml}$ de uma suspensão de $5 \times 10^{4}$ zoosporos/ml, no colo de plântulas com 15 dias apos a emergência.

3.4. Estudo de Herança da Resistência Juvenil em C.annuum a P.capsici

3.4.1. Genotipos Ut i 1 izados

CNPH 148 - Linha selecionada do material "Serrano Criollo de Morelos 334" (CM 334) com resistência a P.capsici. Possui um nivel elevado de resistência na fase juvenil.

CNPH 173 - Selecionada da população BGH 3036 , com resistência a P.capsici na fase adulta. Possui resistência juvenil intermediaria.

CNPH 192 - Cultivar comercial Magda da AGROFLORA. Suscetfvel a P.capsici.

Tabela 01 . Genotipos de Capsicum sp. avaliados para resistência a Phytophthora capsici.

\begin{tabular}{|c|c|c|}
\hline $\begin{array}{c}\text { NUMERO } \\
\text { CNPH }\end{array}$ & POPULACÕES & PROCEDÊNCIA \\
\hline 148 & CM 334 & México \\
\hline 173 & BGH 3036 & Brasil \\
\hline 192 & $\mathrm{Magda}$ & Brasil \\
\hline 134 & BGH 176 & Brasi 1 \\
\hline 181 & Pimentão Amarelo & Brasil \\
\hline 679 & $P I \quad 159236$ & EUA \\
\hline 33 & Long sweet Yel low & EUA \\
\hline 143 & $\mathrm{MC}-4$ & Malasia \\
\hline 640 & Gol iat & Hungria \\
\hline 1397 & Pimenta & Brasil \\
\hline 660 & Fry King & EUA \\
\hline 726 & PI 281341 & El Salvador \\
\hline 730 & PI 338490 & Bulgaria \\
\hline 750 & PI 390966 & Hungria \\
\hline 912 & Pimenta Roxa Grande & Brasil \\
\hline
\end{tabular}


Tabela 01. Gentipos de Capsicum sp. avaliados para resistência a Phytophthora capsici (continuação).

\begin{tabular}{|c|c|c|}
\hline $\begin{array}{c}\text { NUMERO } \\
\text { CNPH }\end{array}$ & POPULACÕES & PROCEDÊENCIA \\
\hline 920 & $\operatorname{Aji}$ Amari110 & Chile \\
\hline 961 & Pimenta Malagueta & Brasil \\
\hline 991 & C. baccatum & Hol anda \\
\hline 994 & Corne di Toro-Rosso & Italia \\
\hline 989 & C. baccatum & Hol anda \\
\hline 971 & Olho de peixe & Brasil \\
\hline 1359 & C. baccatum & Brasil \\
\hline 968 & Cereja & Brasil \\
\hline 727 & PI 281383 & México \\
\hline 966 & Goliat & Hungria \\
\hline 1362 & C. baccatum & Brasil \\
\hline 973 & Pimenta Peão Grande & Brasil \\
\hline 972 & Pimenta Amarela & Brasil \\
\hline 970 & Pimenta de Cheiro & Brasil \\
\hline 51 & Pimenta Fina & Brasil \\
\hline 28 & Rocoto & Peru \\
\hline 2663 & Pimenta Alongada & Bras i 1 \\
\hline 403 & BGH 2926 & Brasil \\
\hline 579 & Pimenta Doce & Brasil \\
\hline 2653 & Pimenta Alongada & Brasil \\
\hline 1393 & Malagueta Mi uda & Brasil \\
\hline 2174 & CM 331 & México \\
\hline 1378 & $38-63-3$ & EUA \\
\hline 287 & Pimenta Malagueta & Brasil \\
\hline 2657 & Pimenta & Bras i 1 \\
\hline 2196 & Ant ibois & França \\
\hline 2659 & Pimentäo & Brasil \\
\hline 1424 & C. baccatum & Brasil \\
\hline 2630 & Calatauco & Argentina \\
\hline 2171 & CM 320 & México \\
\hline 1387 & Mallorca-Paprika & Brasil \\
\hline$=2172$ & CM 325 & México \\
\hline 2200 & Pimenta de Cheiro & Brasil \\
\hline 2272 & Porto Rico Wonder & Brasil \\
\hline 974 & Peão Verde-Amarelo & Brasil \\
\hline 2652 & Pimenta & Brasil \\
\hline 1397 & Pimenta & Brasil \\
\hline 2176 & $\mathrm{CM} 334$ & México \\
\hline 1386 & Pimenta Arapiraca & Brasil \\
\hline 1375 & Early Callwonder & EUA \\
\hline 2658 & Pimenta & Brasil \\
\hline 1402 & Mallorca Doce & Brasil \\
\hline 2582 & Rubi King Gigante & Argentina \\
\hline
\end{tabular}


Tabela 01. Genotipos de Capsicum sp. avaliados para resistência a Phytophthora capsici (continuação).

\begin{tabular}{lll}
\hline $\begin{array}{c}\text { NUMERO } \\
\text { CNPH }\end{array}$ & POPULACÕES & PROCEDÊNCIA \\
\hline 1361 & C. baccatum & \\
2175 & CM 333 & Brasil \\
2661 & Pimenta & México \\
1379 & XVR-3-25 & Peru \\
1374 & C. chinense & EUA \\
1376 & 10 R & Brasil \\
675 & PI 135824 & EUA \\
674 & PI 109252 & Afeganistão \\
684 & PI 164557 & Turquia \\
713 & PI 222134 & Espanha \\
708 & PI 196575 & Espanha \\
681 & PI 163184 & Argentina \\
709 & PI 201241 & India \\
649 & Pant-C-1 & Mexico \\
646 & Hatvani Hajtato & EUA \\
676 & PI 135873 & Hungria \\
677 & PI 138562 & Paquistão \\
706 & PI 193469 & Irã \\
686 & PI 164847 & Etiopia \\
645 & Gigante Amarelo & India \\
191 & Agronômico 10-G & Brasil \\
\hline
\end{tabular}

\subsubsection{Cruzamentos}

Os cruzamentos dirigidos e autofecundações foram feitos em casa-de-vegetação. Na véspera da antese os botões foram emasculados e, uma vez feita a polinização, foram cobertos por um cone de papel alum nio fechado na base para evitar contaminação.

Foram feitos os seguintes cruzamentos:

CNPH 148 X CNPH 192

CNPH $192 \times$ CNPH 148

$\mathrm{CNPH} 173 \times \mathrm{CNPH} 192$

CNPH $192 \times$ CNPH 173

Os hibridos $F 1$ obtidos foram autofecundados (inclusive os recf procos) e retrocruzados com as respectivas 
linhas parentais, a fim de se obter as gerações $F_{2} e$ retrocruzamentos $\left(R C_{1}\right.$ e $\left.R C_{2}\right)$.

\subsubsection{Ava li ação}

Sementes de todas as geraçōes $\left(F_{1}, R C_{1}, R C_{2}, F_{2}\right.$ e reciprocos) como seus progenitores, foram semeados em caixas de plástico $\left(\begin{array}{cccccc}40 & x & 30 & X & 10 & c m\end{array}\right)$ contendo solo esterilizado. Cinco fileiras, com 8 plantas por fileira, foram plantadas em cada caixa. Foram avaliadas 80 plantas das gerações $F_{1}, R C_{1}$ e seus progenitores, e 280 plantas da geração segregante $\mathrm{F}_{2}$.

As plantas foram inoculadas com 15 dias apos a emergência, com uma suspensão de $5 \times 10^{4}$ zoosporos/ml $(3 \mathrm{ml} /$ planta). A temperatura média máxima durante o perfodo de execução do experimento foi $26^{\circ} \mathrm{C}$ e a minima de $16^{\circ} \mathrm{C}$. A avaliação foi feita no 42 e 82 dias apos a inoculação.

A comparacao entre cruzamentos recf procos nas geracoes $F_{1}, R C_{1}, R C_{2}$ e $F_{2}$ foi feita através do teste de XQuadrado (SNEDECOR \& COCHRAN, 1980). A avaliação das taxas de segregacao entre plantas resistentes e suscetfreis nas gerações $F_{1}, R C_{1}, R C_{2}$ e $F_{2}$, também foi feita pelo teste de XQuadrado (SNEDECOR \& COCHRAN, 1980). 
4. RESUltados E DISCUSSÃO

4.1. Padronização do Método de Avaliação de Resistência na Fase Juvenil

4.1.1. Efeito da Data de Avaliação

A melhor data de avaliação para resistência de C.annuum a P.capsici, apos a inoculação, foi estudada separadamente em plantas com 10,15 e 20 dias apos a emergência (d.a.e.).

Independente da idade da planta, os sintomas começarama manifestar-se a partir do $3^{0} \mathrm{dia}$ apbs a inoculação (d.a.i.).

As avaliações foram feitas diariamente até o $16^{\circ}$ dia, através da contagem do numero de plantas tombadas. Foram verificadas diferenças significativas entre os genotipos quanto a resposta à inoculação, durante o perfodo de avaliação.

Para plantas com 10 d.a.e., a partir do $4^{0}$ d.a.i. a suscetibilidade ou resistência manifesta-se em sua totalidade (figura 01.). As plantas que tombam apos este período não contribuiram significativamente na resposta dos materiais testados. O genot i po resistente CNPH 148 manteve-se inalterado ao longo do peŕodo de avaliação. No $3^{0}$ d.a.i. estava definida a resposta de resistência de CNPH 173 a $P$. capsici, enquanto que o genotipo CNPH 192 manifestou 

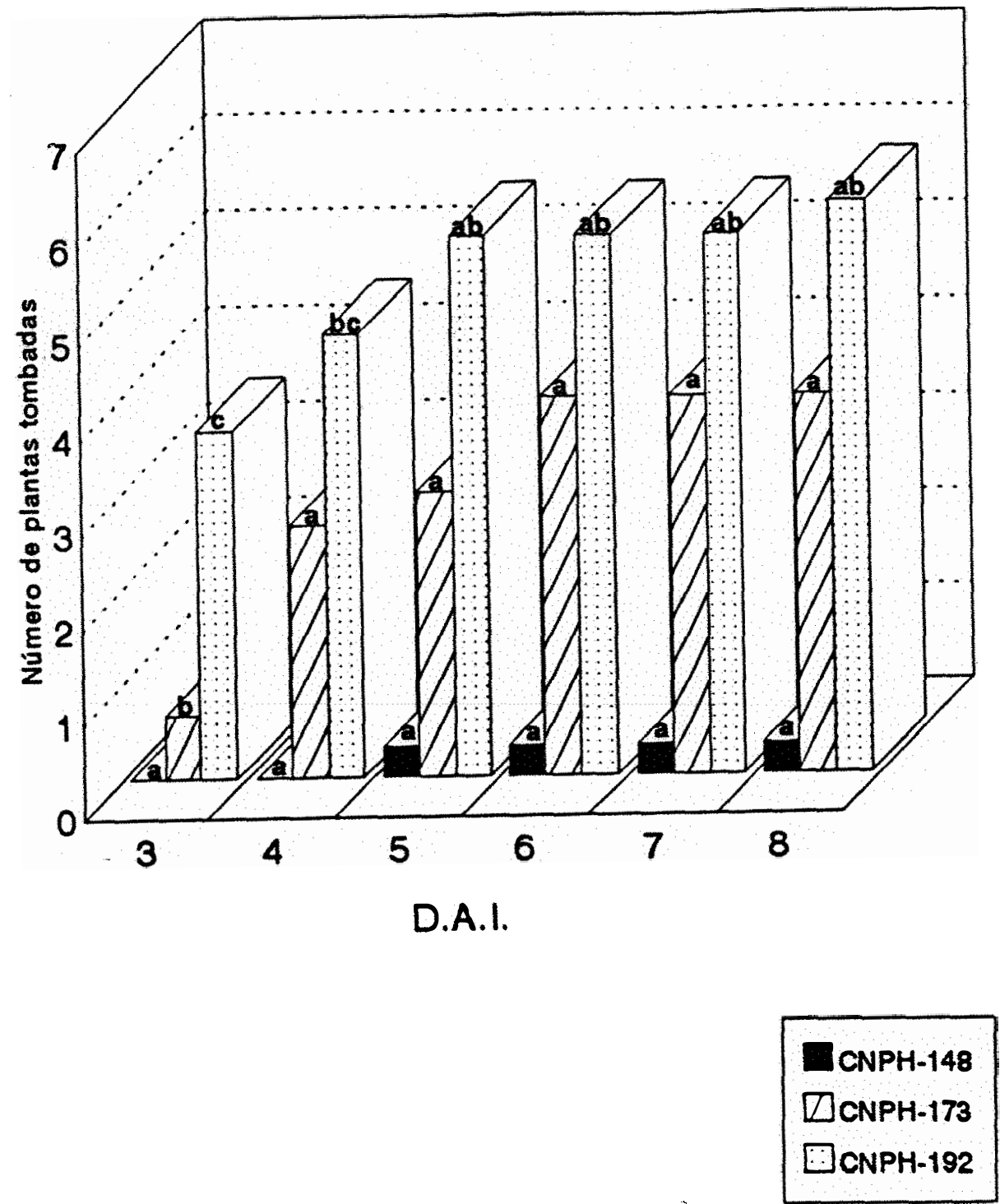

Figura 01. Namero médioll de plantas $(10$ d.a.e.) tombadas dos genotipos CNPH 148,173 e 192 , do 32 ao 82 dias apos a inoculação (D.A.I.) com Phytophthora capsici $\left(10^{4}\right.$ zoosp./ml).

$/ 1$ Média de 4 repetições ( 7 plantas/rep.), comparadas pelo teste de Tukey $(5 \%)$. Analise realizada sobre valores transformados para $\sqrt{ } \mathrm{x}+$ $0.5(\mathrm{CV}=6,41 \%)$. 


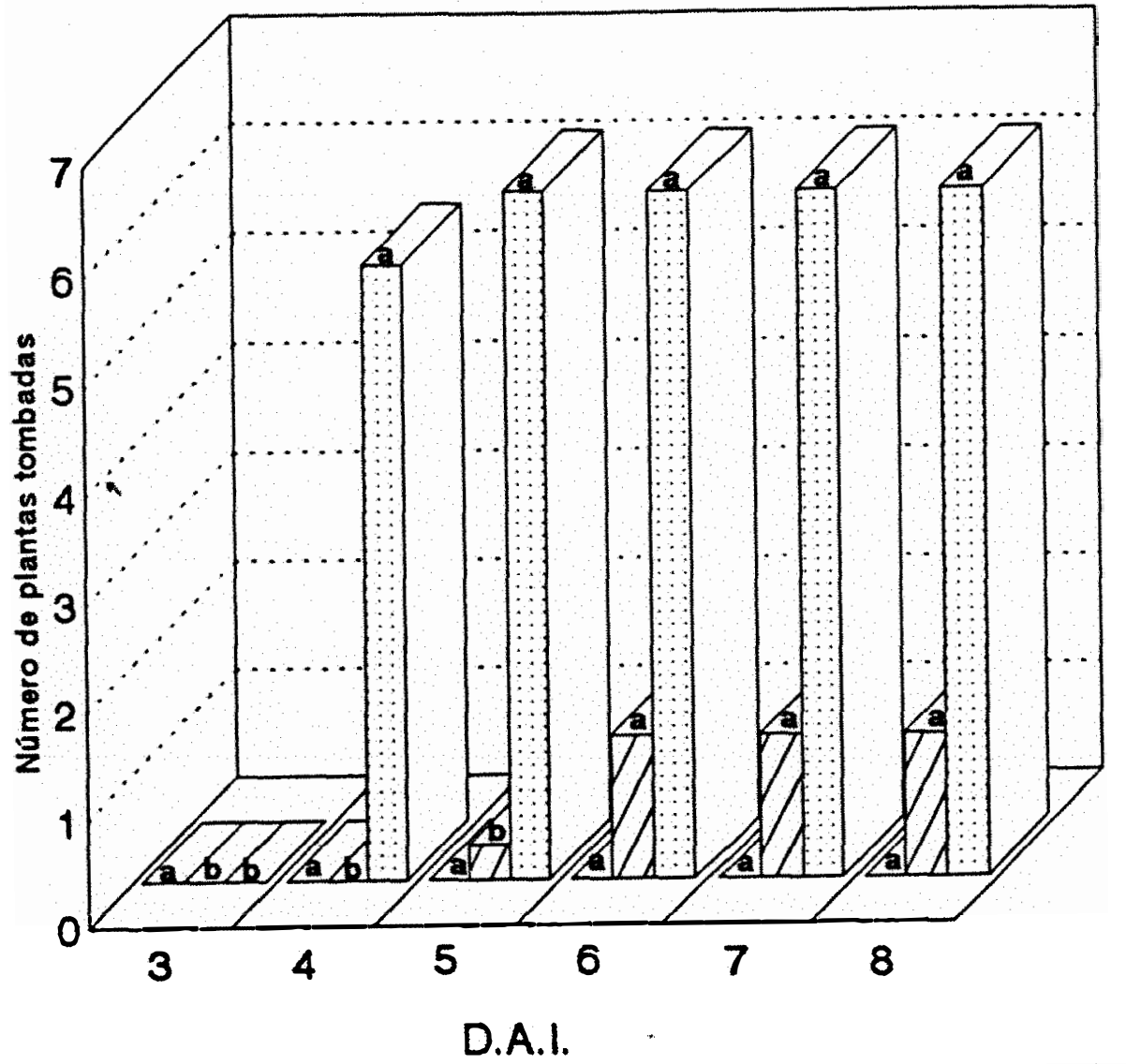

\section{DCNPH-148 \\ D $\mathrm{CNPH}-173$ \\ CNPH-192}

Figura 02. Numero médio ${ }^{11}$ de plantas $(15$ d.a.e.)tombadas dos genotipos $\mathrm{CNPH} 148,173$ e 192 , do 32 ao 82 dias apos a inoculação (D.A.I.) com Phytophthora capsici $\left(10^{4}\right.$ zoosp./ml).

$/ 1$ Média de 4 repetições ( 7 plantas/rep.), comparadas pelo teste de Tukey $(5 \%)$. Análise realizada sobre valores transformados para $\sqrt{ } \mathrm{x}+$ $0.5(\mathrm{CV}=7.14 \%)$. 
praticamente toda sua suscetibilidade no $5^{0}$ d.a.i. (Figura 01.). Os oito genotipos que também foram avaliados (não constam nas figuras) comportaram-se como altamente suscetf veis, e do $4^{\circ}$ ao $16^{\circ}$ dias não houve diferenças entre as aval i ações.

Houve um retardamento no inf cio do tombamento em plantas com $15 \mathrm{~d} . \mathrm{a} . \mathrm{e}$. Apesar de os sintomas começarem a aparecer no $3^{0} \mathrm{~d} . \mathrm{a} . \mathrm{i} .$, a maioria das plantas tombaram no $5^{\circ}$ d.a.i. (figura 02.). O genotipo CNPH 148 comportou-se como a ltamente resistente, enquanto que até o $6^{\circ} \mathrm{d} . \mathrm{a} . \mathrm{i}$. ainda tombavam plantas de $\mathrm{CNPH}$ 173. Apenas com 3 dias apos a inoculação o genot i po CNPH 192 diferiu significativamente dos demais. Os genotipos tiveram a suscetibilidade manifestada em sua totalidade no $5^{\circ} \mathrm{d} . \mathrm{a} . \mathrm{i}$..

O comportamento de plantas com 20 d.a.e.foi semelhante ao de plantas com 15 dias, ou seja, a resposta dos genotipos na manifestação dos sintomas parece estar definida no $5^{\circ}$ d.a.i. (figura 03.). Alguns genotipos suscetfreis responderam ma is lentamente à inoculação, ou seja, so a partir do $7^{0} \mathrm{~d} . \mathrm{a} . \mathrm{i}$. é que não houve diferença significativa entre as datas de avaliação. Este resultado nos leva a concordar com alguns pontos defendidos por MATSUOKA \& ANSANI (1984), no que diz respeito a influência da idade na velocidade com que as plantas morrem; plantas mais jovens tendem a entrar em colapso total mais rapidamente do que plantas mais velhas.

Com base nestes resultados, adotamos duas datas de avaliação, no $4^{0}$ e $8^{0}$ dias apos a inoculação. A leitura no $8^{0}$ d.a.i. garantiu a confiabilidade dos dados. 


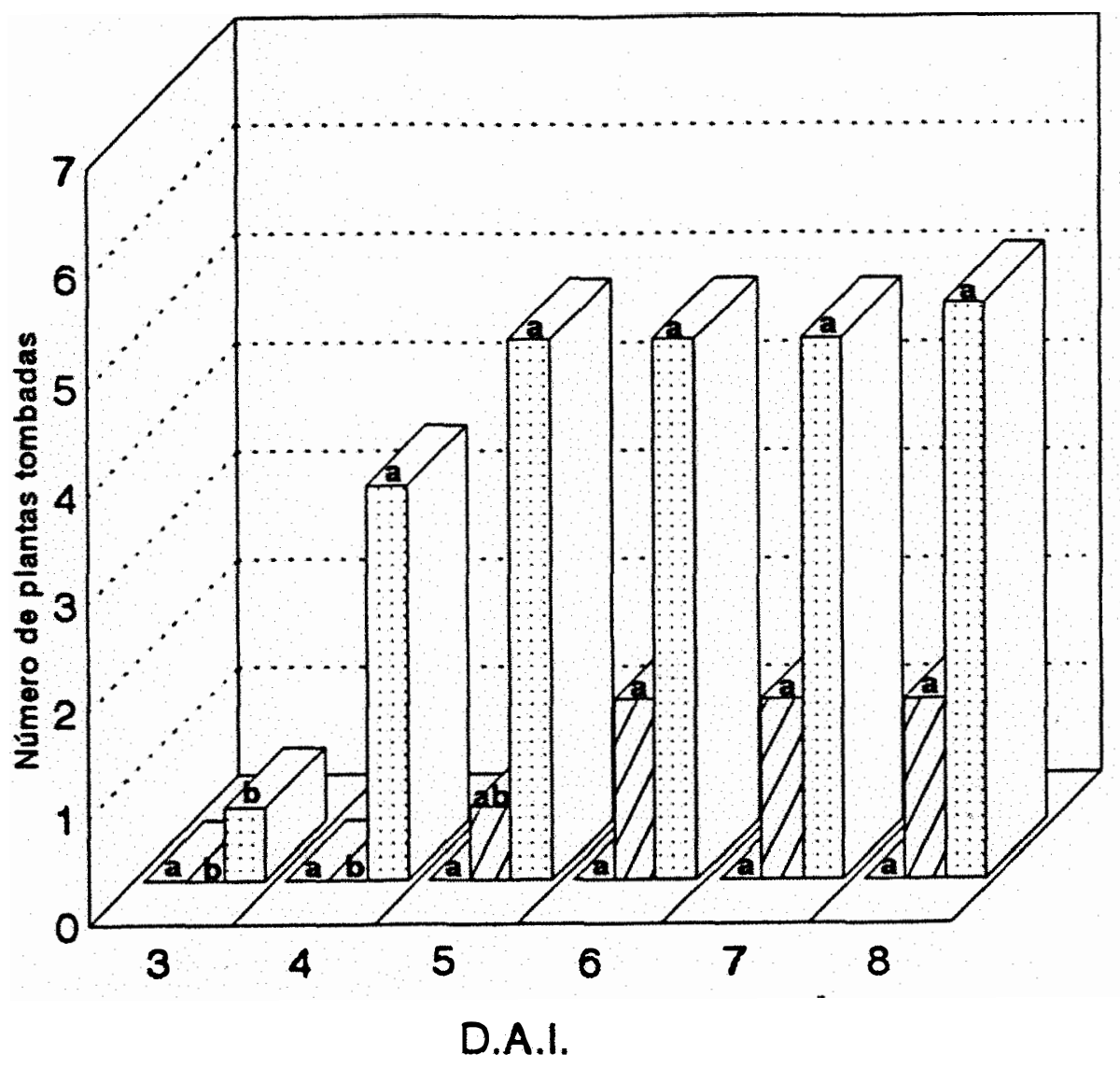

\section{CNPH-148 \\ $\square \mathrm{CNPH}-173$ \\ DCNPH-192}

Figura 03. Namero médio $/ 1$ de plantas $(20$ d.a.e.) tombadas dos genotipos CNPH 148,173 e 192 , do 32 ao 82 dias apos a inoculação (D.A.I.) com Phytophthora capsici $\left(10^{4}\right.$ zoosp./ml).

11 Média de 4 repetições ( 7 plantas/rep.), comparadas pelo teste de Tukey $(5 \%)$. Análise realizada sobre valores transformados para $\sqrt{ } x+$ $0.5 \quad(\mathrm{CV}=9.42 \%)$. 
4.1.2. Efeito da Concentração de Inoculo

Das cinco concentrações testadas inicialmente, apenas $5 \times 10^{4}$ zobsporos/ml ( $\left.3 \mathrm{ml} / \mathrm{planta}\right)$ causou 0 tombamento total das plantas do genbtipo suscetf vel CNPH 192 , com 15 d.a.e. (figura 04.). A concentração $10^{4}$ zobsp./ml não diferiu significativamente de $5 \times 10^{4}$ zoosp./ml. O genotipo CNPH 173 teve $39 \%$ das tombadas com a dose de inoculo de $5 \mathrm{X}$ $10^{4} \mathrm{zobsp} / \mathrm{ml}$ no primeiro ensaio $(\mathrm{CV}=23,83 \%)$, enquanto que no segundo $0 \%$ de plantas nas duas concentrações testadas (CV $=12,46 \%)$.

Em plantas com 7 dias foram testadas as concentrações $5 \times 10^{4}, 10^{5}$ e $5 \times 10^{5}$ zoosp./ml. Não houve diferença diferença significativa entre as três concentrações avaliadas, todas causaram tombamento das plantas do material suscetíl $1 \mathrm{CNPH} 192$ e não alteraram a resposta de CNPH 148 e CNPH 173 (tabela 02.). CNPH 173 tem se mostrado muito instavel quanto a expressão de sua resistência, que varia a cada ensaio, o que não a contece com CNPH 148.

A partir deste experimento foi adotada a concentração $5 \times 10^{4}$, mais eficiente do que $10^{4}$ zoosp./ml, uma vez que não permitiu escapes, além de não ter diferido significativamente de $10^{5}$ e $5 \times 10^{5} z 0 b s p \cdot / m l$ e de não ter alterado o comportamento do genotipo resistente. Resultado semelhante foi obtido por ANSANI \& MATSUOKA (1983c) e REIFSCHNEIDER et a l. (1986b).

Os resultados podem ser influenciados por altos nf́leis de inoculo, que não representam a relação infeç̧ão-inoculo que ocorre no campo (KIM et al., 1989; BOWERS \& MITCHELL, 1991). A taxa de doença geralmente é maior em casa-de-vegetação do que no campo (REIFSCHNEIDER et al., $1986 b)$. 


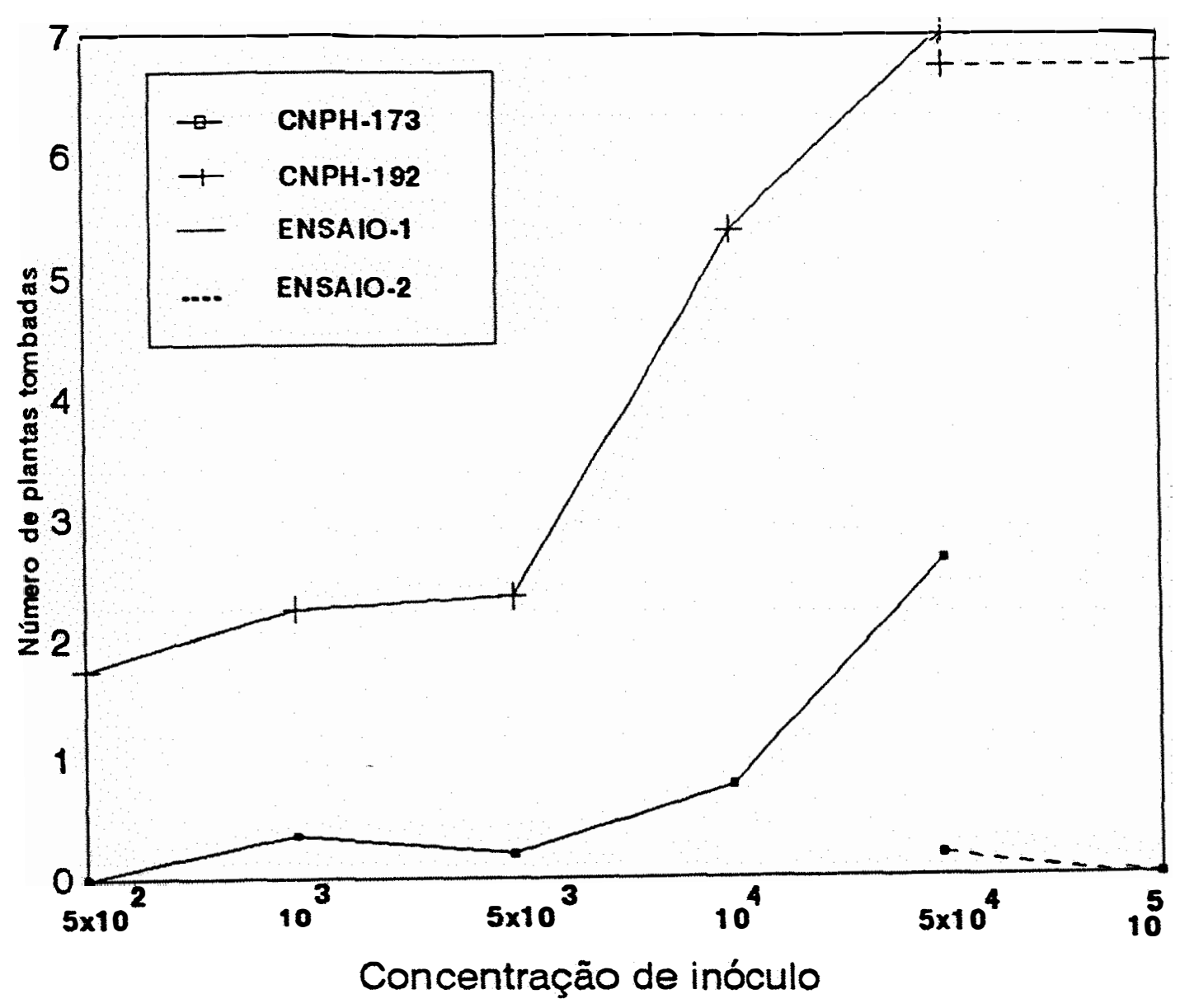

Figura 04. Efeito de seis concentrações de inoculo (zoosp/ ml) de Phytophthorá capsici sobre o numero de plantas tombadas de CNPH 173 e 192 inoculadas com 15 d.a.e..

$/ 1$ Média de 4 repetições $(7$ plantas/rep.). 
Tabela 02. Numero médioll de plantas tombadas de três genotipos de Capsicum annuum, inoculados com três concentrações de Phytophthora capsici aos 7 dias apos a emergência (d.a.e.).

\begin{tabular}{lccc}
\hline \multirow{2}{*}{ GENÓTIPOS } & \multicolumn{3}{c}{ CONCENTRAC̣ÕES } \\
\cline { 2 - 4 } & $5 \times 10^{4}$ & $10^{5}$ & $5 \times 10^{5}$ \\
\hline CNPH 148 & $0,00 \mathrm{~b} *$ & $0,00 \mathrm{~b}$ & $0,00 \mathrm{~b}$ \\
$\mathrm{CNPH} 173$ & $0,20 \mathrm{~b}$ & $0,43 \mathrm{~b}$ & $0,50 \mathrm{~b}$ \\
$\mathrm{CNPH} 192$ & $7,00 \mathrm{a}$ & $7,00 \mathrm{a}$ & $7,00 \mathrm{a}$ \\
\hline $\mathrm{CV}(\%)^{12}$ & & 12,21 & \\
\hline
\end{tabular}

11 Cada valor representa a média de 4 repetições $(7$ plantas/repetição).

12 A analise foi realizada sobre valores transformados para $\sqrt{ } \mathrm{x}+0.5$.

* Médias seguidas pela mesma letra não diferem entre si pelo teste de Tukey ao nivel de $5 \%$ de probabilidade.

A infectividade dos zoosporos também pode variar com o método de inoculação utilizado e por perfodos prolongados de incubação (KIM et al.,, 1989). Outro fator importante é a mobilidade de zoosporos, que quando encistados são menos virulentos do que quando moveis (ANSANI \& MATSUOKA, 1983b); provavelmente os zoosporos moveis têm maior possibilidade de atingir o sitio de infecção, enquanto que os encistados, além de não se locomoverem, germinam e tornam-se mais suscetfveis à lise por antagonistas ( MC INTOSH, 1972; citado por ANSANI \& MATSUOKA, 1983b).

STOLZY et al. (1965), citados por ANSANI \& MATSUOKA (1983b), observaram que o tempo de saturação do solo 
é mais importante que a frequência de irrigação para produção e movimentação de zoosporos de P.citrophthora e P.parasitica.

\subsubsection{Efeito de Temperatura na Expressão da Resistência}

A temperatura média maxima de $38,9^{\circ} \mathrm{C}$, os genotipos CNPH 148, CNPH 173 e CNPH 192 quando inoculados aos 10 e 15 dias de idade, com $3 \mathrm{ml}$ de $10^{4}$ zossp./ml, não diferiram um do outro ( tabela 03.). Nos dois ambiente com plantas com 10 d.a.e. do genotipo $\mathrm{CNPH} 173$ comportaram-se como intermediárias em relação a CNPH 148 e CNPH 192, resistente e suscetivel respectivamente (tabela 03.).

Ut ilizando-se uma concentração de inoculo de $5 \times 10^{4}$ zoosp./ml, plantas do genotipo CNPH 173 com 7 d.a.e. mostraram-se parcialmente resistentes nos dois ambientes avaliados. CNPH 173 foi mais resistente aos 14 d.a.e., nos dois ambientes, não diferindo significativamente de CNPH 148 (tabela 04.).

O genotipo resistente mantem-se praticamente inalterado aos efeitos de temperatura, que exerce maior influência nos materiais com resistência intermediaria e suscetfvel. Resultados semel hantes foram obtidos por ORTEGA et a 1. (1984a), que trabalhararam com temperatura maxima de $25,0 \pm 3,7^{\circ} \mathrm{C}$ e a temperatura mf nima de de $15,7 \pm 2,5^{\circ} \mathrm{C}$ em um ambiente, e temperatura maxima de $18,8 \pm 2,9^{\circ} \mathrm{C}$ e temperatura mf nima de $12,0 \pm 1,3^{\circ} \mathrm{C}$ em outro. No ambiente mais quente os genotipos mais suscetfveis foram os mais atacados por $P$. capsici, enquanto que as resistentes não

foram afetadas pela temperatura.

Apesar de não haver diferença entre os dois ambientes testados, o ambiente com temperatura mais baixa permitiu uma melhor diferenciação entre genotipos resistentes e suscetfveis, principalmente em plantas com 7 d.a.e.. A temperatura pode afetar a doença tanto através do patogeno 
como alterando a eficacia do mecanismo de resistência do hospedeiro (ALON et al., 1974). Além disso, a temperatura em torno de $26^{\circ} \mathrm{C}$ aproxima-se da ideal para o crescimento do fungo em cultura (ALIZADEH \& TSAO, 1984) e ja foi indicada para a avaliação e seleção para a resistência de C.annuum a P.capsici (ORTEGA et al., 1987).

Tabela 03. Efeito da temperatura no numero médioll de plantas tombadas de três genotipos de Capsicum annuum inoculados com Phytophthora capsici, aos 10 e 15 d.a.e. $\left(10^{4}\right.$ zoosp./ml).

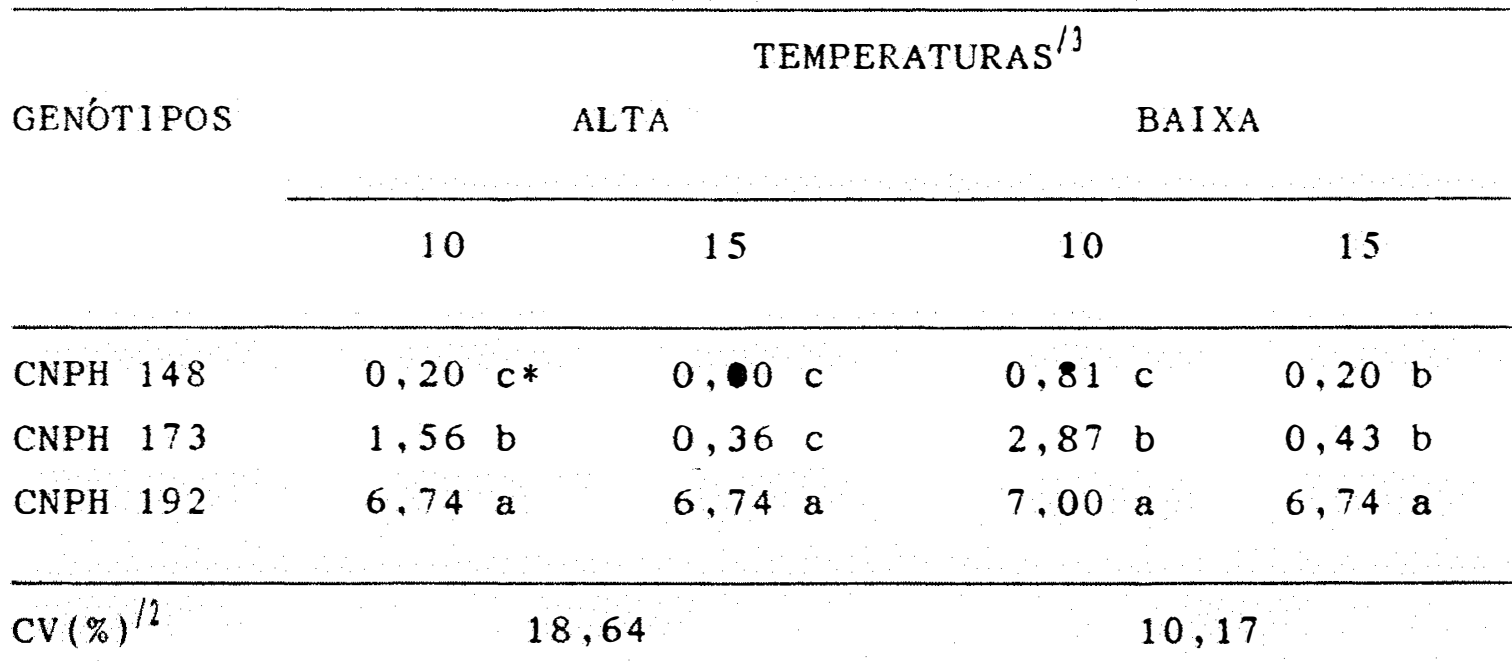

1 Cada valor representa a média de 4 repetições $(7$ plantas/repetição.

12 A analise foi realizada sobre valores transformados para $\sqrt{ } \mathrm{x}+0.5$.

13 ALTA $\mathrm{Zmax}=38,9^{\circ} \mathrm{C}$ e $\mathrm{Zmi} \mathrm{n}=20,4^{\circ} \mathrm{C}$

BAIXA $\max =27,5^{\circ} \mathrm{C}$ e $\operatorname{tmi} \mathrm{n}=17,7^{\circ}$

* Médias seguidas pela mesma letra não diferem entre si pelo teste de Tukey ao nivel de $5 \%$ de probabilidade. 
Tabela 04. Efeito da temperatura no numero médioll de plantas tombadas de três genotipos de Capsicum annuum inoculados com Phytophthora capsici, aos 7 e 14 d.a.e. $\left(5 \times 10^{4}\right.$ zoosp./m1).

TEMPERATURAS ${ }^{13}$

GENÓTIPOS

ALTA

BA I XA

\begin{tabular}{llll}
\hline 7 & 14 & 7 & 14
\end{tabular}

CNPH 148

$0,00 c^{*}$

$0,00 \mathrm{c}$

$0, \bullet c$

$0,00 \mathrm{c}$

CNPH 173

$1,90 \mathrm{~b}$

$0,77 \mathrm{c}$

$2,70 \mathrm{~b}$

$0,00 \mathrm{c}$

CNPH 192

6,74 a

6,74 a

7,00 a

7,00 a

$\operatorname{CV}(\%)^{12}$

7,27

7,77

11 Cada valor representa a média de 4 repetições $(7$ plantas/repetição)

12 A analise foi realizada sobre valores transformados para $\sqrt{ } \mathrm{x}+0,5$.

13 ALTA $7 \max =38,7^{\circ} \mathrm{C}$ e $\operatorname{tmi} \mathrm{n}=20,8^{\circ} \mathrm{C}$

BAIXA $\operatorname{tmax}_{\max }=26,3^{\circ} \mathrm{C}$ e $\operatorname{tmr} \mathbf{n}=15,9^{\circ} \mathrm{C}$

* Médias seguidas pela mesma letra não diferem entre si pelo teste de Tukey ao nivel de $5 \%$ de probabilidade.

\subsubsection{Efeito de Idade da Planta}

Não houve diferença significativa entre as idades avaliadas $(10,15,20$ e 25 d.a.e.), na resposta de cada genotipo estudado. Os genotipos CNPH 148 e CNPH 173 mostraram-se resistentes a partir de $10 \mathrm{~d} . \mathrm{a} . \mathrm{e}$. , quando inoculados com $3 \mathrm{ml}$ de uma suspensão de $10^{4}$ zoosp./ml. Na idade mais jo- 
vem, algumas plantas do genotipos CNPH 148 e CNPH 173 tombaram, mas não foi significativa a incidência da doença quando comparada com o padrão suscetíl, CNPH 192 (figura 05. ).

Quando foi ut ilizada uma concentração de inoculo maior $\left(5 \times 10^{4}\right.$ zobsp./ml), o genotipo CNPH 173 comportou-se como parcialmente resistente aos 7 d.a.e., diferindo de CNPH 148, que manteve-se resistente e de CNPH 192 Aos 14 d.a.e. as plantas de CNPH 173 mostraram-se resistentes, como CNPH 148 (tabela 05.$)$.

Comparando os resultados contidos nas figuras 05. e 06., observa-se que $\mathrm{CNPH} 173$ não apresentou nenhum sintoma da doença a partir dos 20 d.a.e., enquanto que o genotipo CNPH 192 a partir de 28 d.a.e. apresentou um nível maior de resistência, chegando a comportar-se como "resistente" aos 35 dias (figura 06.) Este resultado contraria os obtidos por BANJA (1989), onde este material mostrou-se suscetfrel aos 45 dias apos a semeadura.

Os resultados obtidos neste experimento, sob condiçōes controladas de temperatura, umidade de solo e concentração de inoculo, contrariam a maioria dos trabalhos sobre a inf luência de idade na expressão de resistência em Capsicum ao fungo P.capsici. Para ANSANI \& MATSUOKA (1983c) a idade do hospedeiro não inf luenciou a infectividade dos zoosporos de P.capsici. o perlodo de tempo maior dispendido na manifestação de sintomas por plantas de pimenta adultas é provavelmente devido a areas maiores de raiz e hipocotilo a serem colonizadas até que a planta entre em colapso total.

Normalmente a resistência a P. capsici é expressada em plantas adultas de pimenta (KIM et al., 1989). Cronologicamente, o período em que os materiais com resistência na fase adulta de ixam de se comportar fenotipicamente como suscetfveis, inicia-se a partir do estadio de seis foIhas (POCHARD \& CHAMBONNET, 1971), ou de 40 dias apos a semeadura (POCHARD et a l., 1986), ou de $40-47$ dias apos a semeadura (CAFE-FILHO \& REIFSCHNEIDER, 1983), ou ainda de 31 
dias apos a semeadura (MATSUOKA et al., 1984).

O primeiro trabalho a relatar a possibilidade de diferenciação entre plântulas de pimenta resistentes e suscetf ve is a $P$. capsici, com 14 dias apos a emergência foi de BOSLAND \& LINDSEY (1991). No presente trabalho, o material CNPH 148 tem reagido consistentemente de um teste a outro, ou seja, a partir de 7 d.a.e. tem se mostrado resistente a $P$. capsici. BOSLAND \& LINDSEY (1991) trabalharam com a linha "Criollo de Morelos 334", genotipo que deu origem a CNPH 148.

A resistência relacionada a idade em plantas de Capsicum pode ser resultado de alteraçoes fisiologicas nos tecidos de rafzes e caule durante o desenvolvimento, que são primariamente dependentes do genotipo da planta (KIM et al., 1989). Estudos fisiologicos e anatômicos poderão ser necessarios para elucidar as causas da resistência relacionada a idade de plantas de capsicum a $P$. capsici (REIFSCHNEIDER et al, 1986b; KIM et al., 1989). 


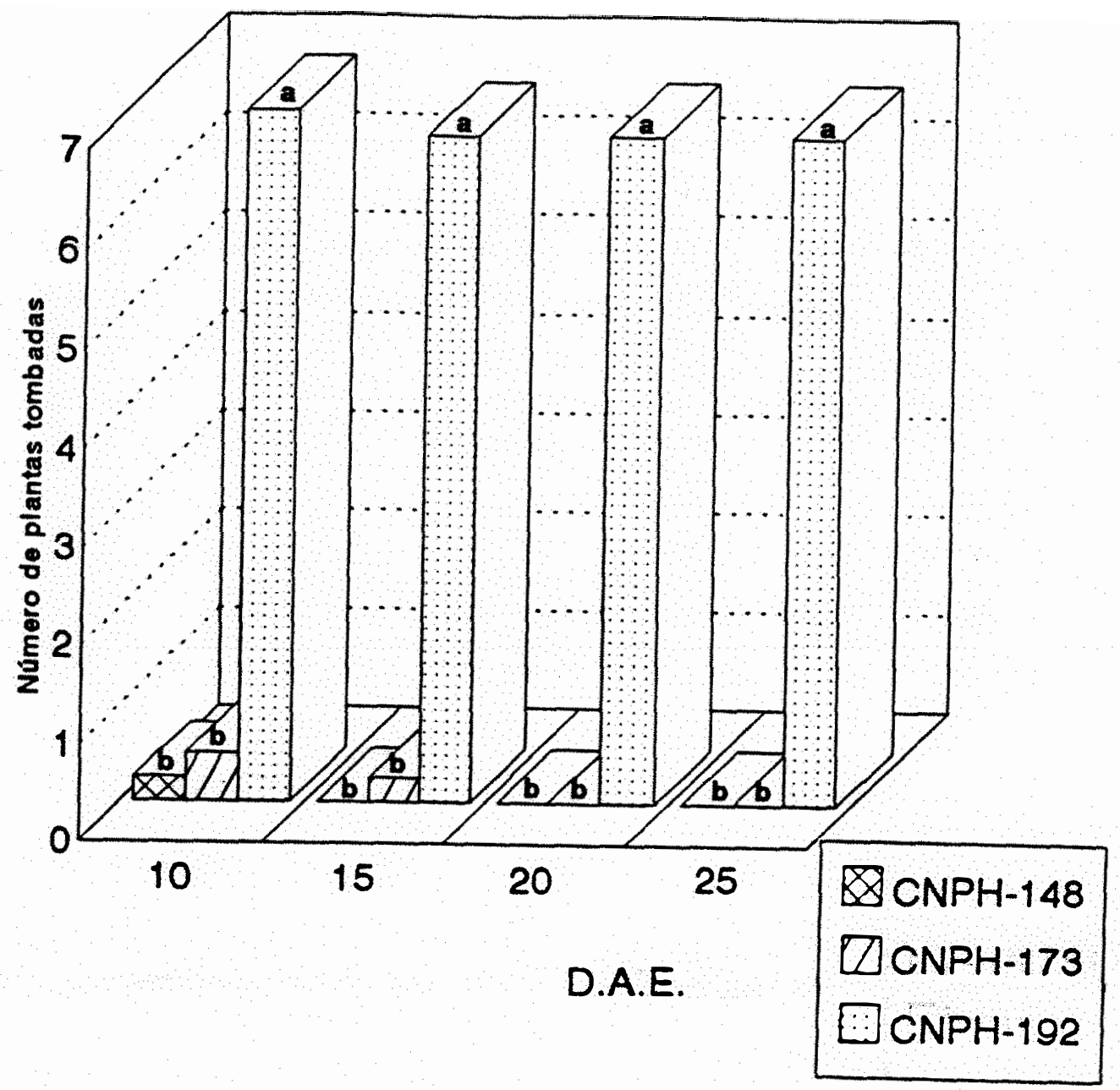

Figura 05. Numero médioll de plantas tombadas de três genotipos de Capsicum annuum inoculados com Phytophthora capsici $\left(10^{4}\right.$ zoosp./ml) em quatro idades diferentes (dias apos a emergência D.A.E.).

$/ 1$ Média de 4 repetições $(7$ plantas/rep.), comparadas pelo teste de Tukey (5\%)). Analise feita sobre valores transformados para $\sqrt{ } \mathrm{x}+0.5$ $(C V=13,11 \%)$. 


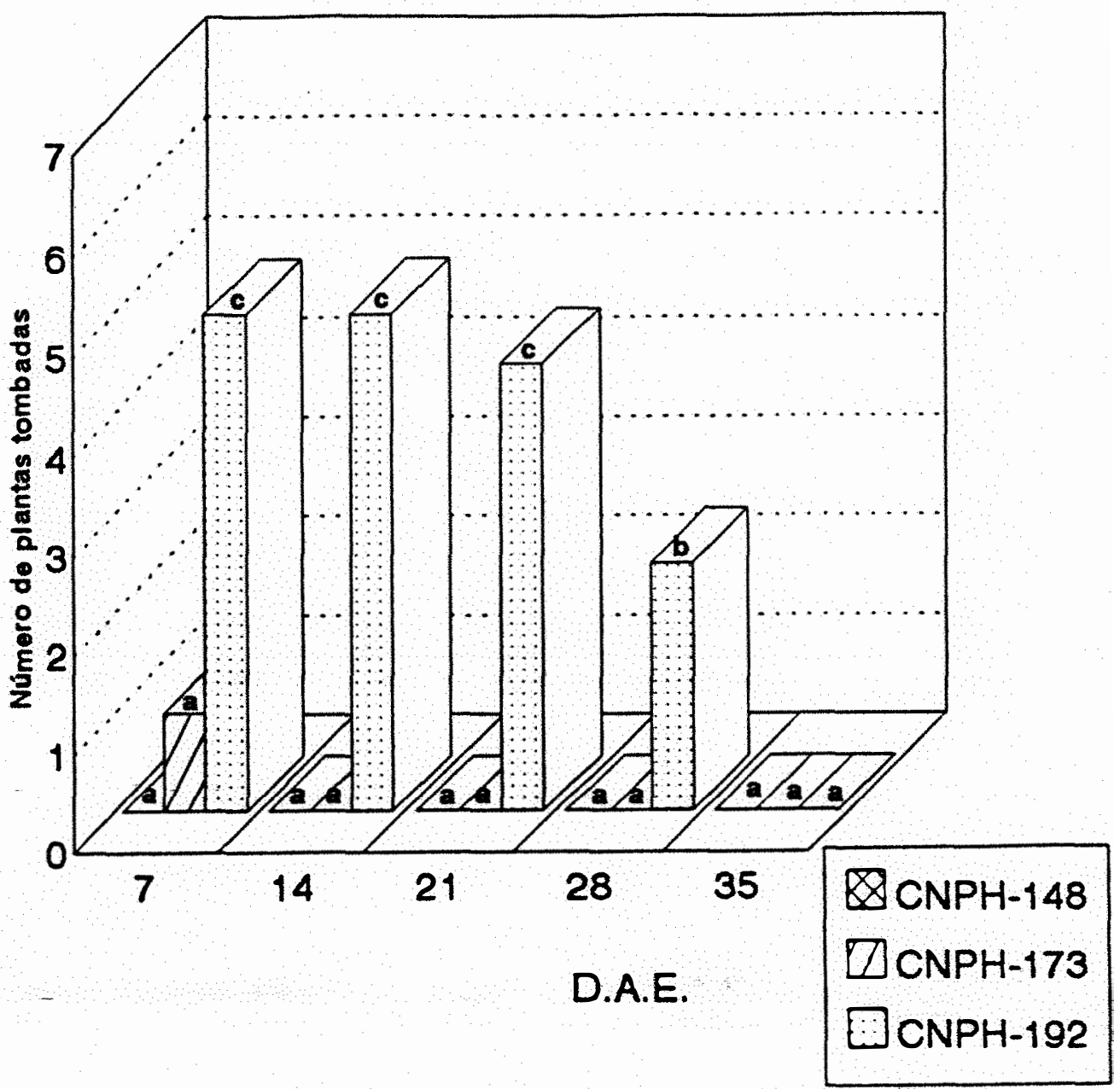

Figura 06. Efeito da idade de planta (D.A.E.) na data de inoculação com Phytophthora capsici sobre o numero médioll de plantas tombadas de três genotipos de Capsicum annuum ( $5 \times 10^{4}$ zoosp./ml).

$/ 1$ Média de 4 repetições $(7$ plantas/rep.) comparadas pelo teste de Tukey $(5 \%)$. Analise feita sobre valores transformados para $\sqrt{ } \mathrm{x}+0.5$ $(\mathrm{CV}=1,33 \%)$. 
Tabela 05. Numero médioll de plantas tombadas de três genotipos de Capsicum annuum inoculados aos 7 e 14 dias apos a emergência (d.a.e.) com Phytophthora capsici $\left(5 \times 10^{4}\right.$ zoosp./ml).

\section{IDADES}

GENOT I POS

7

14

$\begin{array}{llll}\text { CNPH } 148 & 0,00 \mathrm{c}^{*} & 0,00 \mathrm{c} \\ \mathrm{CNPH} & 173 & 2,70 \mathrm{~b} & 0,00 \mathrm{c} \\ \text { CNPH } 192 & 7,00 \mathrm{a} & 7,00 \mathrm{a}\end{array}$

$$
\mathrm{CV}(\%)^{12}
$$

7,77

11 Cada valor representa a média de 4 repetições ( 7 plantas/repetição).

12 A analise foi realizada sobre valores transformados para $\sqrt{ } \mathrm{x}+0,5$.

* Médias seguidas pela mesma letra não diferem entre si pelo Teste de Tukey (5\%).

\subsection{Avaliação da Resistência na Fase Juvenil de Genotipos de Capsicum}

No primeiro experimento, onde foram avaliados 10 genótipos, destacou-se CNPH 134, com um bom nivel de resistência na fase juvenil a P.capsici; este genotipo foi selecionado da população BGH 176 (Viçosa-MG), com resistência na fase adulta (tabela 06.).

No segundo experimento, de 9 genotipos avaliados, o unico material que diferiu significativamente do genotipo suscetfvel CNPH 192 foi CNPH 961 (tabela 07. ), embora CNPH 726 não tenha diferido de CNPH 961 . O genotipo $\mathrm{CNPH} 961$ é uma pimenta do tipo malagueta, coletada em 
Petrolina (PE).

$\mathrm{Na}$ tabela 08. , correspondente ao terceiro experimento, destacam-se, com um bom ní vel de resistência, as introduções CNPH 989 e CNPH 992, ambos pertencente a espécie C.baccatum, que não diferiram entre si, mas não apresentaram nível de resistência tão alto como o CNPH 148 .

Os melhores resultados foram obtidos no quarto experimento, onde 10 populações comportaram-se como altamente resistentes . Dentre os materiais, merecem destaque os genotipos CNPH 1393, uma pimenta malagueta, e CNPH 2174 , CNPH 2171, CNPH 2172, CNPH 2176 e CNPH 2175, selecionatas da variedade "Serrano Criollo de Morelos", con pelo menos $97 \%$ de plantas sobreviventes (tabela 09.). O genotipo CNPH 2661, uma introdução do Peru, apresentou $93,7 \%$ de plantas sobreviventes na nossa a̛aliação.

A maioria dos materiais que se mostraram promissores nesta avaliação foi coletada no Brasil, como CNPH 1393 (BA), CNPH 287 (GO), CNPH 1424 (DF), CNPH 974 (CE), CNPH 2652 (SC), CNPH 1397 (GO), CNPH 1386 (AL), CNPH 2658 (SC) e CNPH 1361 (SC).

No quinto experimento, todos os materiais avaliados mostraram-se suscetfveis, com exceção de CNPH 649, com um nf vel intermediario de resistência, quando comparado a CNPH 148 e CNPH 192 ( tabela 10.).

Todos os genotipos que apresentaram um bom nivel de resistência ao serem avaliados quando inoculados aos 15 dias apos a emergência devem ser reavaliados aos 7 d.a.e.. Apesar de constatadas variações no nf vel de resistência a $P$. capsici em função da idade da planta na época de inoculação, plântulas do genotipo CNPH 148 mostraram-se resistentes a partir de 7 d.a.e.. Adotar-se um critério de avaliação inicial em plântulas com 7 d.a.e. poderáa resultar em uma forte pressão de seleção, mascarando eventualmente o efeito de genes menores na resistência, mencionados por ORTEGA\& ESPAÑOL (1983). 
Tabela 06. Reação de populações de Capsicum sp. a Phytophthora capsici (plantas foram inoculadas com 15 d.a.e.).

\begin{tabular}{|c|c|c|}
\hline $\begin{array}{l}\text { NUMERO } \\
\text { CNPH }\end{array}$ & POPULACÕES & $\begin{array}{l}\text { NUMERO DE } \\
\text { PLANTAS TOMBADAS }\end{array}$ \\
\hline 148 & CM 334 & $0,00 \quad b *$ \\
\hline 173 & BGH 3036 & 1,29 \\
\hline 192 & Magda & 6,68 a \\
\hline 134 & BGH 176 & 0,86 \\
\hline 181 & Pimentão Amarelo & 7,00 a \\
\hline 679 & PI 159236 & 5,90 a \\
\hline 33 & Long Sweet Yell ow & $6,68 a$ \\
\hline 143 & $\mathrm{MC}-4$ & $4,97 \mathrm{a}$ \\
\hline 640 & Goliat & $7,00 \quad a$ \\
\hline 1397 & Pimenta & $6,68 \mathrm{a}$ \\
\hline
\end{tabular}

11 Cada valor representa a média de 4 repetições (7 plantas/repetição). A analise foi realizada sobre valores transformados para $\sqrt{ } \mathrm{x}+0,5 \quad(\mathrm{CV}=13,01 \%$; $\mathrm{QME}=0,062$ ).

* Médias seguidas pela mesma letra não diferem entre si pelo teste de Tukey (5\%). 
Tabela 07. Reação de populações de Capsicum sp. a Phytophthora capsici (plantas foram inoculadas com 15 d.a.e.).

\begin{tabular}{ccc}
\hline $\begin{array}{r}\text { NUMERO } \\
\text { CNPH }\end{array}$ & POPULAÇOES & $\begin{array}{c}\text { NUMERO DE } \\
\text { PLANTAS TOMBADAS }\end{array}$ \\
\hline 192 & Magda & $5,50 \mathrm{a}^{\mathrm{a}}$ \\
660 & Fry King & $6,68 \mathrm{a}$ \\
679 & PI 159236 & $5,65 \mathrm{a}$ \\
726 & PI 281341 & $4,47 \mathrm{ab}$ \\
730 & PI 338490 & $5,30 \mathrm{a}$ \\
750 & PI 390966 & $6,31 \mathrm{a}$ \\
912 & Roxa Grande & $5,65 \mathrm{a}$ \\
920 & Aji Amari110 & $6,68 \mathrm{a}$ \\
961 & Malagueta & $1,63 \mathrm{~b}$ \\
\hline
\end{tabular}

11 Cada valor representa a média de 4 repetiçóes $(7$ plantas/repetição). A analise foi realizada sobre valores transformados para $\sqrt{ } \mathrm{x}+0,5$ ( $C V=12.04 \%$; $\mathrm{QME}=0,097$ ).

* Médias seguidas pela mesma letra não diferem entre si pelo teste de Tukey $(5 \%)$. 
Tabela 08. Reação de populações de Capsicum sp. a $P$. capsici (plantas inoculadas com 15 d.a.e.)

NUMERO

$\mathrm{CNPH}$
POPULAĈ̣̃ES

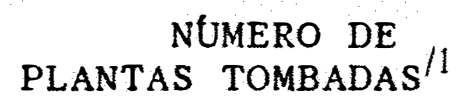

\begin{tabular}{rll}
\hline 148 & CM 334 & $0,00 \quad \mathrm{f*}$ \\
192 & Magda & $7,00 \mathrm{a}$ \\
991 & C. baccatum & $7,00 \mathrm{a}$ \\
994 & Corne di Toro-Rosso & $7,00 \mathrm{a}$ \\
989 & C. baccatum & $1,46 \mathrm{de}$ \\
971 & Olho de Peixe & $6,73 \mathrm{ab}$ \\
1359 & C. baccatum & $5,50 \mathrm{ab}$ \\
992 & C. baccatum & $2,39 \mathrm{~cd}$ \\
1295 & Rubi King & $4,20 \mathrm{bc}$ \\
990 & C. baccatum & $7,00 \mathrm{a}$ \\
1364 & C. baccatum & $4,56 \mathrm{ab}$ \\
968 & Cereja & $6,73 \mathrm{ab}$ \\
727 & PI 281383 & $7,00 \mathrm{a}$ \\
966 & Goliat & $7,00 \mathrm{a}$ \\
1362 & C. baccatum & $5,21 \mathrm{ab}$ \\
973 & Peão Grande & $5,45 \mathrm{ab}$ \\
972 & Pimenta Amarela & $7,00 \mathrm{a}$ \\
970 & Pimenta de Cheiro & $6,73 \mathrm{ab}$ \\
\hline
\end{tabular}

11 Cada valor representa a média de 4 repeticoes(7 plantas/repetiçãol. A analise foi feita sobre valores transformados para $\sqrt{ } \mathrm{x}+0,5(\mathrm{CV}=8.66 \%, \mathrm{QME}=0,038)$.

* Médias seguidas pela mesma letra não diferem entre si pelo teste de Tukey ( $5 \%$ ). 
Tabela 09. Reação de populações de Capsicum sp. a $P$. capsici ( plantas inoculadas com 15 d.a.e.).

\begin{tabular}{|c|c|c|c|}
\hline $\begin{array}{r}\text { NUMERO } \\
\text { CNPH }\end{array}$ & POPULACOOES & $\begin{array}{r}\text { NUMERO I } \\
\text { PLANTAS }\end{array}$ & $\begin{array}{l}\text { DE } \\
\text { TOMBADAS }\end{array}$ \\
\hline 148 & CM 334 & 0,00 & $e^{*}$ \\
\hline 192 & Magda & 6,73 & $a b$ \\
\hline 51 & Pimenta Fina & 7,00 & $a$ \\
\hline 28 & Rocoto & 6,46 & $a b$ \\
\hline 2663 & Pimenta Alongada & 5,70 & $a b c$ \\
\hline 403 & BGH 2926 & 5,70 & $a b c$ \\
\hline 579 & Pimenta Doce & 6,46 & $a b$ \\
\hline 2653 & Pimenta Alongada & 2,77 & abcde \\
\hline 1393 & Malagueta Miuda & 0,00 & $\mathrm{e}$ \\
\hline 2174 & $C M \quad 331$ & 0,00 & e \\
\hline 1378 & $38-63-3$ & 6,46 & $a b$ \\
\hline 287 & Pimenta Malagueta & 0,91 & cde \\
\hline 2657 & Pimenta & 6,26 & $a b$ \\
\hline 2196 & Ant ibois & 6,20 & $a b$ \\
\hline 2659 & Pimentão & 6,46 & $a b$ \\
\hline 1424 & C. baccatum & 1,69 & abcde \\
\hline 2630 & Calatauco & 6,73 & $a b$ \\
\hline 2171 & CM 320 & 0,00 & e \\
\hline 1387 & Mallorca-Paprika & 1,24 & bcde \\
\hline 2172 & CM 325 & 0,20 & $\mathrm{e}$ \\
\hline 2200 & Pimenta de Cheiro & 1,66 & abcde \\
\hline 2272 & Porto Rico Wonder & 2,99 & abcde \\
\hline 974 & Peão Verde-Amare 10 & 1,69 & abcde \\
\hline 2652 & Pimenta & 1,48 & abcde \\
\hline 1397 & Pimenta & 0,50 & $\mathrm{de}$ \\
\hline 2176 & CM 334 & 0,00 & $\mathrm{e}$ \\
\hline 1386 & Pimenta Arapiraca & 0,20 & $\mathrm{e}$ \\
\hline
\end{tabular}


Tabela 09. Reação de populações de Capsicum sp. a Phytophthora capsici (plantas inoculadas com 16 d.a.e.). (continuação)

\begin{tabular}{lcc}
\hline NUMERO & POPULAC̣OEES NUMERO DE \\
CNPH & PLANTAS TOMBADAS
\end{tabular}

\begin{tabular}{lll}
\hline 1375 & Early Callwonder & 5,60 abc \\
2658 & Pimenta & 2,39 abcde \\
1402 & Mallorca Doce & 3,18 abcde \\
2582 & Rubi King Gigante & 6,20 ab \\
1361 & C. baccatum & 3,03 abcde \\
2175 & CM 333 & 0,20 e \\
2661 & Pimenta & 0,44 de \\
1379 & XVR-3-25 & 2,45 abcde \\
1374 & C. chinense & 2,45 abcde \\
1376 & 10 R & 2,45 abcde \\
\hline
\end{tabular}

11 Cada valor representa a média de 4 repetições (? plantas/rep.) A analise feita sobre valores transformados para $\sqrt{ } \mathrm{x}+0,5(\mathrm{CV}=27.45 \%, \mathrm{QME}=0,227)$.

* Médias seguidas pela mesma letra não diferem entre si pelo teste de Tukey $(5 \%)$. 
Tabela 10. Reação de populações de Capsicum sp. a $P$. capsici (plantas inoculadas com 15 d.a.e.).

\begin{tabular}{|c|c|c|}
\hline NUMERO & POPULACÕES & NÚMERO DE \\
\hline $\mathrm{CNPH}$ & & PLANTAS TOMBADAS $/ 1$ \\
\hline 148 & CM 334 & 0,00 \\
\hline 192 & Magda & 7,00 a \\
\hline 675 & PI 135824 & 7,00 a \\
\hline 674 & PI 109252 & 6,68 a \\
\hline 684 & PI 164557 & 6,68 a \\
\hline 713 & PI 222134 & 6,68 a \\
\hline 708 & PI 196575 & $7.00 \mathrm{a}$ \\
\hline 681 & PI 163184 & $6,68 \mathrm{a}$ \\
\hline 709 & PI 201241 & $5,95 \mathrm{a}$ \\
\hline 649 & Pant $-\mathrm{C}-1$ & $3,66 \quad b$ \\
\hline 646 & Hatvani Hajtato & $6,68 \mathrm{a}$ \\
\hline 676 & PI 135873 & 6,68 a \\
\hline 677 & PI 138562 & $6,68 \mathrm{a}$ \\
\hline 706 & PI 193469 & 6,31 a \\
\hline 686 & PI 164847 & 6,31 a \\
\hline 645 & Gigante Amarelo & $7,00 \mathrm{a}$ \\
\hline 191 & Agronômico $10-G$ & $7,00 \quad \mathrm{a}$ \\
\hline
\end{tabular}

11 Cada valor representa a média de 4 repetições 17 plantas/repetição). A analise foi realizada sobre valores transformados para $\sqrt{ } \mathrm{x}+0,5 \quad$ ( $C V=8.01 \%$, $\mathrm{QME}=0,039$ ).

* Médias seguidas pela mesma letra não diferem entre si pelo teste de Tukey (5\%). 
Apesar de terem sido descritas muitas fontes de resistência em Capsicum a P. capsici (KIMBLE \& GROGAN, 1960; SOTIROVA et a 1., 1977; MATSUOKA et al., 1984; BANJA, 1989), até o momento não existe no mercado uma cultivar comercial resistente. A determinação de novas fontes pode permitir que se desenvolvam populações com um amplo espectro de genes, tanto para resistência, quanto para adapt ação.

Embora $P$. capsici infecte principalmente o sistema radicular, seria aconselhável a avaliação de resistência da parte aérea das fontes determinadas, uma vez que acredita-se que o controle genético da resistência na parte aérea não é o mesmo da resistência na raiz e colo da planta (REIFESCHNEIDER et a l., 1986b).

Algumas fontes de resistência encontradas neste trabalho pertencem às espécies $C$. baccatum $\mathrm{e}$. chinense, o que não representa problema em futuros cruzamentos com $C$. annuum, pois combinações hł bridas entre diferentes espécies do gênero Capsicum ja foram obtidas. Já C. pubescens esta isolada geneticamente de outras espécies cultivadas (HEISER \& SMITH, 1953; GOVINDARAJAN, 1985).

E importante a avaliação de caracterfsticas agronômicas das fontes de resistência determinadas, como formato de fruto e nfvel de pungência, se for objetivo do programa de melhoramento introduzir a resistência a $P$. capsici em cultivares comerciais de pimentão ou de pimenta-doce.

4.3.Estudo de Herança da Resistência de C. annuum na Fase Juvenil a $P$. capsici.

Durante o perfodo de avaliação, o genotipo CNPH 192 comportou-se como altamente suscetf vel, apresentando baixa porcentagem de plantas sobreviventes. A linha resistente $\mathrm{CNPH} 148$ também apresentou algumas plantas 
tombadas enquanto que CNPH 173 mostrou-se parcialmente resistente.

Não houve diferença significativa entre os cruzamentos recíprocos (SNEDECOR \& COCHRAN,1980). Assim, os dados dos cruzamentos reciprocos foram agrupados, tanto nos retrocruzamentos, quanto nas populações F1 e F, (Tabela 11.).

Foram observadas alterações nas classes fenotípicas nas populações $P_{1}, F_{1}$, RC, (retrocruzamento para o progenitor resistente) e $F_{2}$, que podem ser explicadas por uma penetrância incompleta dos genes que conferem resistência a $P$. capsici em Capsicum. A penetrância média das gerações em questão obtidas do cruzamento entre CNPH 148 e CNPH 192 foi de $95,4 \%$, enquanto que a calculada para CNPH 173 foi $77,4 \%$. Quando os dados foram corrigidos, as segregações em $P_{1}, F_{1}, R C_{1}, R C_{2}$ e $F_{2}$ aproximaram-se de 1:0, $1: 0,1: 0,1: 1$ e $13: 3$, respectivamente, tanto para as obtidas do cruzamento CNPH 148 X CNPH 192 (tabela 12.), quanto do cruzamento CNPH 173 X CNPH 192 (tabela 13.). Estes resultados sugerem que a resistência na fase juvenil em Capsicum annuum envolve dois genes, com epistasia dominante e recessiva. A resistência é devida à interação de um gene dominante e um gene recessivo (PyPycaca), enquanto o comportamento suscetivel do genotipo CNPH 192 é determinado por um gene recessivo e um gene dominante em interação (pypyCaCa), no locus correspondente (figura 07.). Resultados semelhantes foram obtidos por REIFSCHNEIDER et al. (1992), quando estudaram a herança em CNPH 148 na idade adulta, em cruzamento com as cultivares suscetiveis Agronômico 10-G e Yolo Wonder. Estudos conduzidos por BARTUAL et al. (1991) indicam que efeitos de epistasia não podem ser negligenciados na ação de genes responsaveis pela resistência de Capsicum a P.capsici. Os resultados obtidos por BANJA (1989), LOTZ \& COSTA (1991) e REIFSCHNEIDER et al.(1992), embora em fontes de resistência diferentes, indicam que a herança é devida a dois genes com epistasia dominante e recessiva. 
Tabela 11. Comparação entre cruzamentos reciprocos para resistência em Capsicum annuum a Phytophthora capsici.

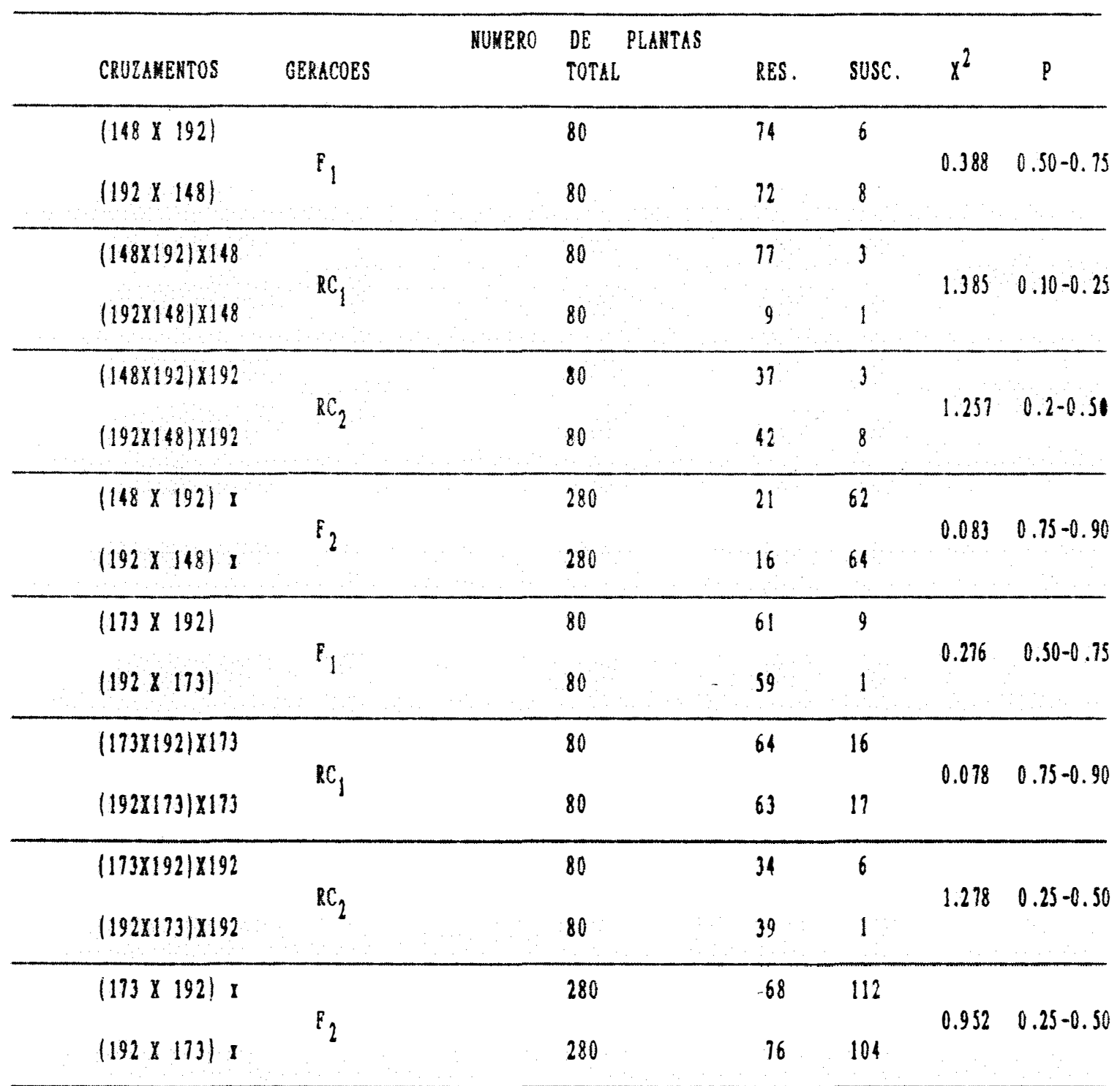


Tabela 12. Dados de segregação para resistência em Capsicum annuum nas gerações parentais $\left(P_{1}\right.$ e $\left.P_{2}\right), F_{1}$, retrocruzamentos( $R C_{1}$ e $\left.R C_{2}\right)$ e $F_{2}$, apos inoculação com Phytophthora capsici (plantas com 15 d.a.e.).

CRUZaMEMTOS geracóes NÓMERO DE PLANTAS

TOTAL $/ 1$ RES. SUSC.

Proporcio $\quad x^{2} / 2, \quad P$

$(R: S)^{\circ} \quad(13: 3)^{*}$

p. 
controlada por um gene dominante, que mais tarde foi confirmado por SOLANES \& LOTTI (1967), enquanto que YAMAKAWA et al. (1979) acreditam tratar-se de um gene com dominância incompleta.

Tabela 13. Dados de segregação para resistência em Capsicum annuum nas gerações parentais ( 1 1 e P2), $F_{1}$, Retrocruzamentos ( $R C 1$ e $R C 2)$ e $F_{2}$, apos inoculação com P.capsici (plantas com 15 d.a.e.).

\begin{tabular}{|c|c|c|c|c|c|c|c|}
\hline CRUZAMENTOS & GERICOES & $\begin{array}{l}\text { We DE PLANTAS } \\
\text { TOTAL }\end{array}$ & RES. & susc. & $\begin{array}{l}\text { PROPORCAO } \\
(R: S)^{\circ}\end{array}$ & $\begin{array}{c}8^{2} / 2 \\
(13: 3)^{*}\end{array}$ & $p$ \\
\hline 173 & $P_{1}$ & 80 & 64 & 16 & $1: 0$ & 0,090 & $(0,75-0,90)$ \\
\hline NPH 192 & $P_{2}$ & 80 & 2 & 78 & $0: 1$ & 0,050 & $(0,75-0,90)$ \\
\hline $173 \times 1921$ & $\mathrm{~F}_{1}$ & 160 & 120 & 40 & $1: 0$ & 0,154 & $(0,50-0,75)$ \\
\hline $173 \times 192 / 1173$ & $\mathrm{RC}_{1}$ & 160 & 127 & 33 & 1:0 & 0,104 & $(0,50-0,75)$ \\
\hline$(173 \times 192 / 8192$ & $\mathrm{RC}_{2}$ & 160 & 73 & 87 & $1: 1$ & 1,223 & $(0,25=0,501$ \\
\hline $173 \times 192 / x$ & $\mathrm{~F}_{2}$ & 560 & 344 & 216 & $13: 3$ & 1,307 & $(0,25-0,50)$ \\
\hline
\end{tabular}

11 Os dados dos cruzamentos recf procos foram agrupados incluindo retrocruzamentos e populações $F_{2}$.

* Existe uma probabilidade de 0,10 de se ter feito uma escolha errada da taxa de segregacão, em função do tamanho da amostra da geração $F_{2}$ (STEEL \& TORRIE, 1960).

12 os valores de $X^{2}$ foram calculados com os dados das geraçōes $P_{1}, F_{1}, R C_{1}$ e $F_{2}$ corrigidos para uma penetrância média de $77,4 \%$. 
Para SMITH et al. (1967) o controle genético da resistência de C.annuum a P.capsici é resultado da ação de dois genes dominantes que atuam independentemente. Heredia (1980) citado por GUERRERO-MORENO \& LABORDE (1980) e GUERRERO-MORENO \& LABORDE (1980) sugeriram dois genes recessivos independentes que interagem diferentemente, de acordo com a virulência de isolados especf ficos de P.capsici, enquanto que SARAIVA (1982) acredita tratar-se de dois genes recessivos e um gene modificador dominante. A presença de genes menores modificadores foi citada por BARKSDALE et al. (1984) para explicar a ocorrência ocasional de plantas de pimenta infectadas com $P$. capsici em populaçoes do progenitor resistente, $F_{1}$ e retrocruzamentos para o parental resistente. POLACH \& WEBSTER (1972), ao estudarem a genética de possiveis raças de $P$. capsici, concluiram que ao menos dois genes determinam a patogenicidade em pimenta.

A contradição entre os trabalhos provavelmente deve-se a diferentes isolados de $P$. capsici e genotipos de Capsicum utilizados, assim como a critérios de avaliação e seleção adotados durante a condução dos ensaios (ORTEGA \& ESPAÑOL, 1982). Para BANJA (1989) toda discordância pode ser explicada pelo modo de ação dos genes envolvidos na resistência de capsicum a P. capsici. Efeitos epistaticos podem explicar os resultados obtidos por GUERRERO-MORENO \& LABORDE (1980), se o progenitor resistente possui o genotipo

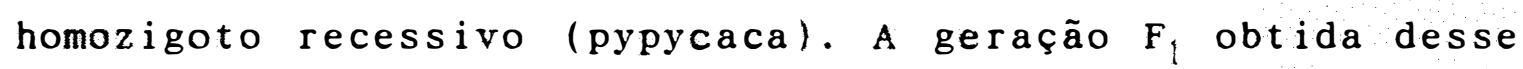
cruzamento comporta-se como suscetfvel, enquanto que a afirmação de SOLANES \& LOTTI (1967) e YAMAKAWA et al. (1979) enquadra-se ao modelo se o progenitor resistente for homozigoto dominante (PyPyCaCa).

A diferença no grau de penetrância entre os genotipos CNPH 148 e CNPH 173 pode ser atribuf da à presença de genes modificadores (Bohn et al., 1940; citados por ALON et a 1., 1974; BARKSDALE et a 1., 1984), que são fortemente afetados por alteraçôes ambientais, como tem sido demonstrado 
em muitos casos de resistência de plantas a doenças (VAN DER PLANK, 1968). Situação seme lhante foi observada entre duas linhas de tomate homozigotas resistentes a Fusarium, cuja resistência é atriburda a um par de genes (ALON et al., 1974). Foi observado que em plantas heterozigotas de tomate, o nível de penetrância do gene para resistência ao vírus TSMV foi reduzido (STEVENS et al., 1992), talvez resultante de alterações do ambiente interno da planta devido a condição de heterozigose.

RETIG et al. (1967), trabalhando com resistência de tomate a Fusarium, consideraram que as modificaçoes no gene l podem ser explicada por uma penetrância incompleta, e com possiveis efeitos da idade da planta na época de inoculação sobre o grau de penetrancia. Outros fatores foram considerados como responsaveis por uma grande variação na penetrância do gene $I$, como temperatura do solo, método de inoculação e diferença de virulência entre os isolados. A temperatura do solo pode afetar a doença através do patogeno, da eficacia do mecanismo de resistência do hospedeiro, ou ainda da atividade da microflora presente no solo (ALON et a 1., 1974). No trabalho desenvolvido por ALON et al. (1974) a penetrância da resistência aumentou substancialmente com o aumento da idade da planta. Verificamos também que a idade das plantas de Capsicum foi o fator que exerceu maior influência na expressão da resistência. Em plantas do genotipo CNPH 173, inoculadas a partir de 21 d.a.e., a penetrância dos genes que conferem resistência a $P$. capsici aumentou, chegando a $100 \%$. Além disso, efeitos de temperatura foram maiores em plântulas de CNPH 173 com 7 e 14 d.a.e. do que em CNPH 148 . 
Figura 07. Esquema de distribuição de genotipos e fenotipos obtidos nas gerações $F_{1}, R C_{1}, R C_{2}$ e $F_{2}$ do cruzamento entre CNPH 148 e CNPH 192.

\begin{tabular}{|c|c|c|c|c|}
\hline$P_{1}$ & $\begin{array}{l}\text { PyPycaca } \\
\text { (R) }\end{array}$ & & $\begin{array}{l}\text { pypycaCa } \\
\text { (S) }\end{array}$ & $P_{2}$ \\
\hline$F_{1}$ & & $\begin{array}{l}\text { Py pyCaca } \\
\text { (R) }\end{array}$ & & \\
\hline $\mathrm{RC}_{1}$ & $\mathrm{Py} \mathrm{Ca}$ & $\mathrm{Py} \mathrm{ca}$ & py Ca & py ca \\
\hline Py ca & $\begin{array}{c}\text { PyPycaca } \\
\text { (R) }\end{array}$ & $\begin{array}{c}\text { PyPycaca } \\
(R)\end{array}$ & $\begin{array}{c}\text { Pypycaca } \\
(R)\end{array}$ & $\begin{array}{c}\text { Pypycaca } \\
\text { (R) }\end{array}$ \\
\hline
\end{tabular}

$\mathrm{RC}_{2}$

\begin{tabular}{|c|cccc|}
\cline { 2 - 6 } \multicolumn{1}{c|}{} & Py Ca & Py ca & py Ca & py ca \\
\hline py Ca & $\begin{array}{c}\text { PypyCaCa } \\
\text { (R) }\end{array}$ & $\begin{array}{c}\text { PypyCaca } \\
\text { (R) }\end{array}$ & pypyCaCa & pypyCaca \\
& $(S)$ & $(S)$ \\
\hline
\end{tabular}

$\mathrm{F}_{2}$

\begin{tabular}{|c|c|c|c|c|}
\hline & $\mathrm{Py} \mathrm{Ca}$ & Py ca & py $\mathrm{Ca}$ & py ca \\
\hline Py $\mathrm{Ca}$ & $\begin{array}{c}\text { PyPyCaCa } \\
\text { (R) }\end{array}$ & $\begin{array}{c}\text { PyPyCaca } \\
\text { (R) }\end{array}$ & $\begin{array}{c}\text { Pypycaca } \\
\text { (R) }\end{array}$ & $\begin{array}{c}\text { PypyCaca } \\
\text { (R) }\end{array}$ \\
\hline $\mathrm{Py} \mathrm{ca}$ & $\begin{array}{c}\text { PyPyCaca } \\
\text { (R) }\end{array}$ & $\begin{array}{c}\text { PyPycaca } \\
\text { (R) }\end{array}$ & $\begin{array}{c}\text { PypyCaca } \\
\text { (R) }\end{array}$ & $\begin{array}{c}\text { Pypycaca } \\
\text { (R) }\end{array}$ \\
\hline py $\mathrm{Ca}$ & $\begin{array}{c}\text { PypyCaCa } \\
\text { (R) }\end{array}$ & $\begin{array}{c}\text { Pypycaca } \\
\text { (R) }\end{array}$ & $\begin{array}{c}\text { pypycaCa } \\
\text { (S) }\end{array}$ & $\begin{array}{c}\text { pypyCaca } \\
\text { (S) }\end{array}$ \\
\hline py ca & $\begin{array}{c}\text { Pypycaca } \\
\text { (R) }\end{array}$ & $\begin{array}{c}\text { Pypycaca } \\
\text { (R) }\end{array}$ & $\begin{array}{c}\text { pypycaca } \\
\text { (S) }\end{array}$ & $\begin{array}{c}\text { pypycaca } \\
\text { (R) }\end{array}$ \\
\hline
\end{tabular}


4.4. Considerações Fina is

A ação gênica epistática e/ou a presença de genes modificadores podem explicar o insucesso na transferência de resistência de $P$. capsici para linhas suscetíleis de pimentão, com perda progressiva de resistência nas gerações sucessivas de retrocruzamentos (BARTUAL et al., 1991). Com a finalidade de aumentar a frequência de alelos desejáveis na população e desenvolver linhas elites pela recombinação de indivfduos superiores, o método de selecão recorrente foi sugerido como o mais efetivo, quando se trata de resistência parcial e/ou poligênica (BARTUAL et al., 1991). E necessário que se tenha, durante as diferentes fases do programa de melhoramento, o máximo controle das condições ambientais, como concentração de inoculo (ORTEGA et al., 1987; PALLOIX et al., 1988b), temperatura (ORTEGA et al., 1987), saturação de agua do solo para aumentar a eficiência de dispersão dos zoosporos (ORTEGA et al., 1990) e a virulência do isolado de P. capsici (REIFSCHNEIDER et al., 1986b). Se estes fatores não forem bem controlados, as respostas das populações segregantes, podem ser alteradas. 


\section{CONCLUSÕES}

Através dos resultados obtidos neste trabalho, estabeleceram-se as seguintes conclusões:

- A padronização da metodologia de avaliação de resistência na fase juvenil em Capsicuma P.capsici, permitiu distinguir plântulas resistentes de suscetíveis a partir de 7 d.a.e. (dias apos a emergência).

- Existe consideravel variabilidade quanto ao nf vel de resistência, no estadio juvenil de plantas de Capsicum spp a P.capsici, entre 80 populações, incluindo as espécies C.annuum, C.baccatum e C.chinense, sobressaindo-se os seguintes materiais como fonte de resistência: CNPH 134, 989 , $1393,2174,2172,2171,287,1397,2176,1386,2175$ e 2661.

- A herança da resistência na fase juvenil encontrada nos genotipos estudados é controlado por dois genes com epistasia dominante e recessiva.

- A penetrância dos genes que conferem resistência a CNPH 173 é em média 77,4\%, enquanto que em CNPH 148 é cerca de $95,4 \%$, em plantas inoculadas com 15 d.a.e.. A penetrância incompleta dos genes, neste caso, deve-se entre outros fatores, principalmente a possf veis efeitos da idade da planta na época de inoculação. 


\section{REFERÊNCIAS BIBLIOGRÁFICAS}

ABAK, K. \& POCHARD, E. Aggressivity of various Phytophthora capsici isolates from Turkey on two partly resistant pepper lines. Capsicum Newsletter, Turin, 3: 65-6, 1984.

ALIZADEH, A. \& TSAO, P. Renaming Phytophthora palmivora MF4 to P.capsici and redescription of the species. phytophthora Newsletter, Bangor, 12: 1-2, 1984.

ALON, H.; KATAN, J., KEDAR, N. Factors affecting penetrance of resistance to Fusarium oxysporum f.sp. Iycopersici in tomatoes. Phytopathology, St. Paul, 64(4):455-60, 1974 .

ANSANI, C.V. \& MATSUOKA, K. SObrevivência de zoosporos e micélios de Phytophthora capsici no solo. Fitopatologia Brasileira, Brasi lia, I: 481, 1982. (Resumo).

ANSANI, C.V. \& MATSUOKA, K. Infectividade e viabilidade de oosporos de Phytophthora capsici no solo. Fitopatologia Brasileira, Brasf 1 ia, $\underline{8}: 137-45,1983 a$.

ANSANI, C.V. \& MATSUOKA, K. Sobrevivência de Phytophthora capsici no solo. Fitopalogia Brasileira, Brasília, $\underline{3}: 269-$ $76,1983 \mathrm{~b}$. 
ANSANI, C.V. \& MATSUOKA, K. Efe ito da densidade de zoosporos e idade de mudas de pimentão (Capsicum annuum) na infectividade de Phytophthora capsici. Fitopatologia Brasileira, Brasflia, 8 : 263-68, $1983 \mathrm{c}$.

BANJA, W.H. Herança de resistência em plantas adultas de Capsicum annuum a Phytophthora capsici Leonian e teste de alelismo. Piracicaba, 1989. 60p. (Mestrado - Escola Superior de Agricultura "Luiz de Queiroz"/USP).

BARKSALE, T.H.; PAPAVIZAS, G.C.; JOHNSTON, S. A. Resistance to foliar blight and crown rot of pepper caused by Phytophthora capsici. plant Disease, St. Paul, 68(6): $506-9,1984$.

BARTUAL, R.; CARB๑NELL, E.A.; MARSHAL, J.I.; TELlO, J.C.; CAMPOS, T. Gene action in the resistance of peppers (Capsicum annuum) to Phytophthora stem blight (Phytophthora capsici L.). Euphytica, Wageningen, 54(2):195-200, 1991 .

BOSLAND, P.W. \& LINDSEY, D.L. A seedling screen for Phytophthora root rot of pepper, Capsicum annuum. Plant. Disease, St. Paul, 75(10): 1048-50, 1991.

BOWERS, S.J.H. \& MITCHELL, D.J. Relationship between inoculum level of phytophthora capsici and mortality of pepper. Phytopathology, St. Paul, $\underline{81}$ : 178-84, 1991.

BYUNG, H.H.; EBRAHIM-NESBAT, F.; IBENTHAL, W.D.; HEITEFUSS, R. An ultrastructural study of the effect of metalaxyl on Phytophthora capsici infected stems of Capsicum annuum. pesticide Science, Oxford, 29: 151-62, 1990. 
CAFE-FILHO, A.C. \& REIFSCHNEIDER, F.J.B. Resistência juvenil de pimentão a Phytophthora capsici. Fitopatologia Brasileira, Brasflia, 11: 295, 1986. (Resumo).

CASALI, V.W.D. \& COUTO, F.A.A. Origem botânica de Capsicum. Informe Agropecuario, Belo Horizonte, 10(113): 8-10, 1984.

CASALI, V.W.D.; PÁDUA, J.G.; BRAZ, L.T. Melhoramento de pimentão e pimenta. Informe Agropecuario, Belo Horizonte, 10(113): $19-22,1984$.

CHOI, K.S.; OM, Y.H.; LEE, J.W. Studies on varietal differences and inheritance of resistence to Phytophthora capsici in red peppers of korea. Capsicum Newsletter, Turin, $\underline{3}: 39-41,1984$.

Clearjeau, M.; PITRAT, M.; NOURRISSEAU, J.G. La resistance du piment (Capsicum annuum) à Phytophthora capsici. IV Etude de l'agressivité de divers isolats au niveau des feuilles, des tiges et du collet de plantes sensibles et resistantes. Annales de Phytopathologie, Paris, $\underline{8}(4)$ : 411-23, 1976 .

costa, G.o. Inoculação maltipla, interações e técnicas de avaliação da reação de Capsicum a três patogenos: Ví rus Y da batata, Phytophthora capsici e Xanthomonas campestris pv.vesicatoria. Brasflia, 1987. 113p. (Mestrado Universidade de Brasi lia).

CRISTINZIO, G.; ZEMA, V.; ERRICO, A.; SACCARDO, F. Introduction of resistance genes to Phytophthora capsici into cultivar of Capsicum annuum "Friariello". In:MEETING GENETICS AND BREEDING ON CAPSICUM AND EGGPLANT, 8., Rome, 1992. Proceedings. Rome, EUCARPIA, 1992. p.189-91. 
DUNIWAY, J.M. Limiting influence of low water potencial on the formation of sporangia by Phytophthora dreschsleri in soil. Phytopathology, St. Paul, 65: 1089-93, 1975.

FERNANDEZ, C.M. Phytophthora capsici causante de la marchitez en pimiento (Capsicun annuum) en Chile. Agricultura TÉcnica, Santiago, 43(2): 91-3, 1983.

FERNANDEZ, C.M. Evaluacion de genotipos para resistencia a Phytophthora capsici Leonian en pimiento y aji (Capsicum annuum). Agricultura Técnica, Santiago, 48(4): 359-62, 1988 .

GOVINDARAJAN, V.S. Capsicum - production, technology, chemistry, and quality. I. History, botany, cultivation and primary processing. CRC Critical Reviews in Food Science and Nutrition, Cleveland, $\underline{22}(2): 109-26,1985$.

GUERRERO-MORENO, A.G. \& LABORDE, J.A. Current status of pepper breeding for resistance to Phytophthora capsici in México. In: MEETING GENETICS AND BREEDING ON CAPSICUM AND EGGPLANT, 4., Wageningen, 1980. Proceedings. Wageningen, EUCARPIA, 1980 . p.52-6.

HEISER Jr, C.B. \& SMITH, P.G. The cultivated Capsicum peppers. Economic Botany, New York, I: 214-27, 1953.

INTERNATIONAL BOARD FOR PLANT GENETIC RESOURCES. Genetic resources of Capsicum. Roma, FAO/IBPGR, 1983.49p.

JimeneZ, J.M.; BUSTAMANTE, E; BeRMÚdeZ, W.; GAMBOA, A. Identificacion $y$ evaluacion de líneas de chile dulce resistentes a marchitez fungosa en costa Rica. Turrialba. San Jose, $\underline{40}(2): 228-34,1990$. 
JOHNSTON, S.A. \& BARKSDALE, T.H. Pepper Phytophthora blight control with resistance. Biological and Cultural Tests, Minnesota, 2. 15,1987 .

KHAN, M.A.; AHMAD, I .; ASLAM, M.; POLITANO, L.; VALGIMIGLI, A.; SACCARDO, F. Development and standardzation of different inoculation methodologies in Chilli peppers (Capsicum annuum) resistant to Phytophthora capsici. In: MEETING GENETICS AND BREEDING ON CAPSICUM AND EGGPLANT, 8., Rome, 1992. Proceedings. Rome, EUCARPIA, 1992. p. 178-83.

KIM, Y.J.; HWANG, B.K.; PARK, K.W. Expression of age related resistance in pepper plants infected with Phytophthora capsici. Plant Disease, St. Paul, 73: 745-7, 1989.

KIM, E.S., \& HWANG, B.K. Virulence to Korean pepper cultivars to isolates of Phytophtora capsici from different geographic areas. Plant Disease, St. Paul, 76: $486-9,1992$.

KIMBLE, K.A. \& GROGAN, R.G. Resistance to Phytophthora root rot in pepper. Plant Disease Reporter, washington, 44(11): $872-3,1960$.

KUNIMOTO, R.K., ARAGAKI, M.; HUNTER, J.E.; KO, W.H. Phytophthora capsici, corrected name for the cause of Phytophthorablight of macadamia racemes. Phytopathology, St. Paul, 66: 546-8, 1976.

LEONIAN, L.H. Stem and fruit blight of peppers caused by Phytophtora capsici sp. Phytopathology, St Paul, 12:4018,1922 . 
LOTZ, I.M.P. \& COSTA, C.P. Heraņ̧a da resistência em Capsicum chinense a Phytophthora capsici. Horticultura Brasileira, Brasf 1 i a , $\underline{9}(1): 43,1991$. (Resumo).

MAFFIA, A.M.C. \& MATSUOKA, K. Transmissão e sobrevivência de Phytophthora capsici em semente de pimentão Capsicum annuum. Fitopatologia Brasileira, Brasi lia, I: 468, 1982 . ( Resumo).

MATSUOKA, K. Melhoramento de pimentão e pimenta visando a resistência a doenças fungicas. Informe Agropecuario. Belo Horizonte, $10(113): 49-52,1984$.

MATSUOKA, K. \& ANSANI, C.V. Formação de oospotos de Phytophthora capsici nos tecidos de pimentão (Capsicum annuum). Fitopatologia Brasileira, Brasilia, 9: 27-36, 1984 .

MATSUOKA, K.; CASALI, V.M.D.; SARAIVA, T.R.C.B. Fontes de resistência à Phytophthora capsici em Capsicum annuum. Fitopatologia Brasileira, Brasi lia, 9: 193-201, 1984.

ORTEGA, R.G. \& ESPAÑOL, C.P. Mejora del pimiento para resistencia a Phytophthora capsici. In: Jornadas de seleccion y mejora de tomate y pimiento, 3., Zaragoza, 1982. Zaragoza, INIA-CRIDA, 1982. p.387-403.

ORTEGA, R.G. \& ESPAÑOL, C.P. A hypothes is to work on pepper breeding for Phytophtora capsici resistance. In:MEETING GENETICS AND BREEDING ON CAPSICUM AND EGGPLANT, 5., Plovdio, 1983. Proceedings. Plovaiv, EUCARPIA, 1983. p. $165-70$. 
ORTEGA, R.G.; ESPAÑOL, C.P.; ZUECO, J.C. Pepper response to Phytophtora capsici Leon. zoospore inoculation. I. Influence of temperature and fungus isolate. Capsicum Newsletter, Turin, $\underline{3}$ : $33-4,1984 \mathrm{a}$.

ORTEGA, R.G.; ESPAÑOL, C.P.; ZUECO, J.C. Pepper response to Phytophtora capsici Leon. zoospore inoculation. II. Influence of plant age and inoculation dose. Capsicum Newsletter, Turin, $\underline{3}$ : $35-6,1984 \mathrm{~b}$.

ORTEGA, R.G.; ESPAÑOL, C.P.; ZUECO, J.C Respuesta del pimiento a la inoculacion con aislamientos de Phytophthora capsici Leon. a diforentes temperaturas. Investigacion Agraria, Produccion y Proteccion Vegetales, Madrid, $2(2)$ : $183-93,1987$.

ORTEGA, R.G.; ESPAÑOL, C.P.; ZUECO, J.C. Genetics of the resistance to Phytophthora capsici in Mexican pepper "Line 29". EPPO Bulletin, Paris, 20: 117-22, 1990.

ORTEGA, R.G.; ESPAÑOL, C.P.; ZUECO, J.C. Genetic relationships among four peppers resistant to Phytophthora capsici. plant Breeding, Berlin, 108: 118-25, 1992.

PALLOIX, A.; DAUBEZE, A.M.; POCHARD, E. Phytophthora root rot of pepper: influence of host genotype and pathogen strain on the inoculum density-disease severity relationships. Journal of Phytopathology, Berlin, $\underline{123}(1): 25-33,1988 \mathrm{a}$.

PALLOIX, A.; DAUBEZE, A.M.; POCHARD, E. Time sequences of root infection and resistance expression in an artificial inoculation method of pepper with Phytophthora capsici. Journal of Phytopathology, Berlin, 123(1): 12-24, 19886. 
PALlOIX, A. ; DAUBEZE, A.M.; PHALY, T.; POCHARD, E. Breeding transgressive lines of pepper for resistance to Phytophthora capsici in a recurrent selection system. Euphytica, Wageningen, 51: 141-50, 1990

POCHARD, E. \& CHAMBONNET, D. Méthodes de sélection du piment pour la resistance au Phytophthora capsici et au virus du concombre. Annales de Faculta Scienzas Agricolas del Universita de Torino, Torino, $I: 270-81,1971$.

POCHARD, E. \& DAUBEZE, A.M. Comparison of three different sources of resistance to Phytophthora capsici in Capsicum annuum. Capsicum Newsletter, Turin, 1: 59-61, 1982.

POCHARD, E.; CLEAJEAU, M.; PITRAT, M, La résistance de piment, Capsicum annuum a Phytophthora capsici Leon. I. Wise en evidence d'une progressive induction de la resistance. Annales de L'Amélioration des Plantes, Paris, $26: 35-50,1976$.

POLACH, F.J. \& WEBSTER, R.K. Identification of strains and inheritance of pathogenicity in Phytophthora capsici. Phytopathology, St. Paul, 62: 20-6, 1972 .

POLTRONIERI, L.S. Produção de esporângio in vitro, patogenicidade em Cucurbita spp. e controle químico de Phytophthora capsici. Piracicaba, 1986. 56 p. (Mestrado-Escola Superior de Agricultura "Luiz de Que iroz"/USP).

RAMIREZ, V.J. \& COVA, S.R. Supervivência de Phytophthora capsici Leon., agente causal de la marchitez del chile. Agrociencia, Chapingo, 39: $9-18,1980$. 
REGO, A.M. \& REIFSCHNEIDER, F.J.B. Levant amento de grupos de compatibilidade de isolados de Phytophthora capsici Leon., obtidos de abobora (Curcubita maxima $x$ Curcubita moschata), pimenta (Capsicum annuum) e pimentão ( $C$. annuum). Fitopatologia Brasileira, Brasilia, 7 : 55-61, 1982 .

REIFSCHNEIDER, F.J.B.; CAFE-FILHO, A.C.; RÊGO, A.M. Comparison of Phytophthora capsici inoculation techniques in sweet-pepper, 1983. Biological and Cultural Tests, Minnesota, 1: 12, $1986 \mathrm{a}$.

REIFSCHNEIDER, F.J.B.; CAFE-FILHO, A.C., REGO, A.M., FaCtors affecting expression of resistance in pepper (Capsicum annuum) to blight caused by phytophthora capsici, in screening trials. Plant Pathology, London, 35: 451-6. $1986 \mathrm{~b}$.

REI FSCHNEIDER, F.J.B.; BOITEUX, L.S.; DELLA VECCHIA, P.T.; POULOS, J.M., KURODA, N. Inher it ance, of adu $1 \mathrm{t}$ plant resistance to Phytophthora capsici in pepper. Euphvtica, Wageningen, $62(1): 45-50,1992$.

RETING, N,; KEDAR, N.; KATAN, J, Penetrance of gene I for Fusarium resistance in the tomato. Euphytica, Wagningen, 16. $252-7,1967$.

RIBEIRO, O.K. Physiology of assexual sporulation and spore germination in Phytophthora. In: ERWIN, D.C.; BARTNICKIGARCIA, S.; TSAO, P.H., ed. Phytophthora, its biology, taxonomy, ecology, and pathology. St. Paul, APS Press, 1987 . p. $55-70$. 
SAINI, S.S. \& SHARMA, P. Inheritance of resistance to fruit rot (Phytophthora capsici Leon.) and induction of resistance in bell pepper (Capsicum annuum L.). Euphytica, Wageningen, 27: 721-3, 1978.

SALGADO, C.L. \& TOKESHI, H. Doenças das Solanaceas. In: GALLI, F., coord. Manual de fitopatologia. 2.ed., São Paulo, Agronômica ceres, 1980, v.2, p.497-510.

SARAIVA, T.R.C.B. Herança da resistência à murcha do pimentão (Capsicum annuum L.) causada por Phytophthora capsici Leonian. Viçosa, 1982. 40p. (Mestrado Universidade Federal de viçosal.

SEGURA, C. B. Busqueda de fuentes de resistencia de aji al hong• Phytophthora citrophthora. Turrialba, San Jose, 12:(1): $16-24,1962$.

SMITH, P.G.; KIMBLE, K.A.; MILLET, A.H. Inheritance of resistance in peppers to phytophthora root rot. Phytopathology, st. Paul, 57(4): 377-9, 1967.

SNEDECOR, G.W. \& COCHRAN, W.G. Statistical methods, 7.ed. Iowa, Iowa State University Press, 1980. 507p.

SOLANES, V.G. \& LOTTI, A. Obtencion de pimiento (Capsicum annuum) resistente a phytophthora. Fitotecnia Lationoamericana, San Jose, $\underline{4}(2): 139-45,1967$.

SOLANES, V.G. \& LOTTI, A. Nueva variedad de pimiento (Capsicum annuum) resistente a Phytophthora capsici. IDIA, San Jose, 271:62-4, 1970 . 
SOTIROVA, V.; DASKALOV, S.; POPOVA, D.; BELEVA, L. Resistance in pepper (C. annuum L.) to Phytophthora capsici Leonian. I. Study on direct and heterotic varieties. In:MEETING GENETIC AND BREEDING ON CAPSICUM, 3., Montfavet, 1977. Proceedings. Montfavet, EUCARPIA, 1977. p. 127-36.

STEEL, R.G.D. \& TORRIE, J.H. Principles and procedures of statistical. New York, McGraw-Hill, 1960. $481 \mathrm{p}$.

STEVENS, M.R.; SCOTT, S.J.; GERGERICH. Inheritance of gene for resistance to tomato spotted wilt virus (TSWV) for Lycopersicum peruvianum Mil1. Euphvtica, Wageningen, 59: $9-17,1992$.

URBEN, A.F. Phytophthora capsici Leonian agente etiologico da murcha de Capsicum annuum L. em Minas Gerais. Viçosa, 1980. 63p. (Mestrado - Universidade Federal de Viçosa).

VAN DER PLANK, J.E. Disease resistance in plants. New York, Academic Press, 1968. 206p.

WATERHOUSE, G.M. The genus of PhVtophthora of Bary: diagnosis (or descriptions) and figures from the original. papers. 2.ed., Kew, Commonwealth Mycological Institute, 1970. 59p. (Mycological papers, 122).

WESTE, G. Population dynamics and survival of Phytophthora. In: ERWIN, D.C.; BARTNICK-GARCIA, S.; TSAO, P.H., ed. phytophthora; its biology, taxonomy, ecology, and pathology. St. Paul, APS Press, 1987. p.237-57. 
YAMAKAWA, K.; MOCHIZUKI, T.; YASUI. H. Screening of cultivated and wild peppers for Phytophthora capsici resistance and its inheritance. Bulletin of the vegetable and Ornamental Crops Research Station. Serie A., Tsu-shi, 6: $29-37,1979$.

ZEMA, V.; CRISTINZIO, G. ; ERRICO, A.; SACCARDO, F. Characterization of resistance to phytophthora capsici i c. frutescens L. In: MEETING GENETICS AND BREEDING ON CAPSICUM AND EGGPLANT, 8., Rome, 1992. Proceedings. Rome, EUCARPIA, 1992 . p.184-8. 